\title{
THE LEGAL REGULATION OF RELIGIOUS SYMBOLS IN THE PUBLIC SPHERE IN SLOVAKIA
}

\author{
VOJTECH VLADÁR
}

\section{Introduction}

In modern societies, the freedom of thought, conscience, and religion is a basic human right. Even continued secularisation cannot reduce its importance. We may therefore describe it as the freedom of freedoms, since many other freedoms are derived from it, including freedom of speech, association, and meeting. ${ }^{1}$ From the point of view of human rights, this freedom is considered fundamental and included among the first generation of human rights. ${ }^{2}$ In the contemporary world, societies that respect and observe human rights are generally perceived to have achieved real democratisation. ${ }^{3}$ Although this topic is-to a significant extent-theoretical in nature, no less importance is attributed to its constitutional, international as well as historical and sociological delimitation. Slovakia is the same in this sense because throughout its history, churches and religious societies (especially the Catholic Church) have played one of the most significant roles. This can be best demonstrated by the large number of people avowing to the religion or to the memberships of any of the churches or religious societies. Moreover, according to the last census of population and housing of 2011, the confession of certain religion declared $76 \%$ of

1 Jäger and Molek, 2007, p. 26n.

2 Madleňáková, 2010, pp. 12 and 36.

3 Čeplíková, 2011, pp. 5 and 7.

Vojtech Vladár (2021) The Legal Regulation of Religious Symbols in the Public Sphere in Slovakia. In: Paweł Sobczyk (ed.) Religious Symbols in the Public Sphere, pp. 171-210. Budapest-Miskolc, Ferenc Mádl Institute of Comparative Law-Central European Academic Publishing. 
population. ${ }^{4}$ These statistics also prove that most citizens of the Slovak Republic see churches and religious societies as an integral part of the social structure and important to their own identities. In the past, representatives of the communist regime, which regarded religious institutions as an ideological enemy, restricted their activities and social influence in every possible way and subjected them to government and economic surveillance and international isolation. ${ }^{5}$

The current status of churches and religious societies in the Slovak Republic proves that the events of November 1989 created unprecedented possibilities, giving religious institutions the opportunity to continue on in their traditional role of forming the nation. The high percentage of religious people and the significant engagement of churches and religious societies in social, educational, and charitable endeavours have influenced the state, as it determines how much and to what extent to cooperate with them, while setting guidelines for areas of common collaboration. First and foremost, the state respects their social and legal status as legal entities sui generis, acknowledging them under certain conditions the status of corporations in public law. Overall, given this cooperation, the mutual relationship between the state and churches and religious societies can be considered more than appropriate, despite certain controversies. In other words, the state has accepted their social status fully and cooperated with them, following the principles of partnership collaboration. ${ }^{6}$ For this reason, the status of churches and religious societies in the Slovak Republic is not simply comparable to their status in other democratic countries, but somewhat better. In most highly-developed states, disputes and conflicts over the use of religious symbols in the public sphere are increasing. In Slovakia, the problem barely exists. This chapter focuses on that question and attempts to clarify it from the point of view of Slovak life and institutions, while also pointing out individual reasons for the status quo. First and foremost, this study considers the historical, axiological, sociological, and religious context, analysing these methodologically, while also examining relevant historical and contemporary phenomena. The final results are synthesised and partially compared with developments in other countries to highlight Slovak peculiarities.

\section{Religious symbols in public spaces}

The fact that the Constitution of the Slovak Republic reflects in its Preamble the Cyrilo-Methodian heritage points out the importance of Christianity and its

\footnotetext{
4 See: https://census2011.statistics.sk/tabulky.html. The author was unable to use the results of the 2021 census, which was in progress while this chapter was being written.

5 Grešková, 2008, p. 10.

6 Čikeš, 2010, pp. 8 and 39.
} 
culture on our historical territory that was situated in the period of Early Middle Ages at the crossroad of power and the cultural-spiritual influences of Christian West and East. ${ }^{7}$ After adopting Western Christianity and accepting the domination of Rome, the spiritual centre of Christianity, during the Great Moravian Empire, the Slovak population was involuntarily incorporated into the Hungarian state, where it remained involuntary for about a thousand years. Since that time, many generations have contributed to the Christianisation and cultivation of the new nation. ${ }^{8}$ As a consequence of longer-term direct contact, the ruling Hungarians adopted the Slavonian religion and law, as well as several words, known as moravisms. From that time forward, the development of the church on Slovak territory depended on the Kingdom of Hungary, to which it was ecclesiastically, as well as politically, subordinated. ${ }^{9}$ After the Battle of Mohács in 1526, a new era began in the church and political history of Hungary, which was thereafter administered by the House of Habsburg. The contemporary religious situation had its roots in the $18^{\text {th }}$ and $19^{\text {th }}$ centuries. From the end of the $18^{\text {th }}$ century onwards, freedom of religion was practiced in the Habsburg Monarchy; even non-Catholic churches began to emancipate. ${ }^{10}$ This period also laid the foundations for contemporary interconnections between the state and churches and religious societies, which depended on the state financially because the sovereigns considered them an effective tool for improving the public morals. ${ }^{11}$ After the Austro-Hungarian Compromise of 1867, the Hungarian state established several religious rules, which differed markedly from the Austrian regulations and significantly influenced developments in Slovakia. ${ }^{12}$ For example, in 1894, the obligatory civil marriages and state registers were established, taking effect on 1 October 1895. From that time forward, public bodies did not accept the judgment of Church tribunals in relation to marriage. ${ }^{13}$ In 1895, the Hungarian legislative assembly declared a general policy of religious tolerance, which, for the first time, allowed all citizens to leave any church or religious society and become officially

7 Cyrilo-Methodian traditions were used to support defense arguments during the national revival in the $19^{\text {th }}$ century, becoming the authentic national Slovak tradition sensu stricto. Marsina, 1985, p. 110. Even nowadays, we find mentions of the contributions made by missionaries to Slovakian education. Orendáč, 2014.

8 From the beginning, Hungary was typical in its tolerance of all Christian rites, especially after the Mongol invasion of 1241, when Vlachs of Romanian nationality who practiced Eastern rite appeared in the territory, alongside the German population. Šabo, 2008, pp. 25-26.

9 Moravčíková, 2003, p. 100.

10 Valeš, 2008, p. 110n.

11 Čikeš, 2010, pp. 16-17.

12 For example, in 1868, liberal politicians in the Hungarian legislative assembly recognised Catholic Church courts only in cases of Catholic marriage; children of mixed marriages had to follow the religion of the same-gender parent and church patronage was completely removed from the education system. Although one liberal Hungarian politician proposed the complete separation of church and state in 1873, the monarch, Franz Joseph I (1848-1916), vetoed this project, forcing the Hungarian legislative assembly to withdraw it. The government's attempt to unleash a culture war was likewise a fiasco. Kumor and Dlugoš, 2004, p. 389.

13 Zák. čl. 31/1894 and 32/1894. 
creedless..$^{14}$ Subsequently, all received churches and religious societies had the recognised status of public-law privileged, independent, and autonomous corporations, providing some functions of state machinery. ${ }^{15}$

Since the Czechoslovak Republic, which came into existence on the ruins of Austro-Hungarian Empire, 'received' Hungarian law and order for its Slovak territory, there were still Hungarian religious rules in force in Slovakia and Carpathian Ruthenia, in accordance with the conditions of the year $1895 .{ }^{16}$ International acceptance of the new state significantly advanced its early diplomatic recognition by the Apostolic See. ${ }^{17}$ Faith withered in much of the Czech nation, following the arraignment of the Catholic House of Habsburg on charges of long-term national servitude. These tendencies were strengthened by Czech liberal-humanistic politicians and intellectuals, who hoped to instigate a culture war, ${ }^{18}$ leading to the sporadic removal of crosses from schools. ${ }^{19}$ The proposal to separate church and state, which was raised in the constituent assembly, was rejected due to opposition from Catholic representatives, especially in relation to Slovakia. ${ }^{20}$ The Catholic Church had a particularly high status and its priests, who belonged to the nation's elite, continually supported the national and political revival of the Slovak nation. ${ }^{21}$ Achieving a separation between church and state could moreover strengthen autonomist and separatist tendencies in Slovakia. ${ }^{22}$ Importantly, the boundaries of Catholic dioceses (especially in Slovakia) did not replicate the boundaries of the state. ${ }^{23}$ Despite the efforts mentioned above, churches and religious societies in the First Czechoslovak Republic continued to hold the status of privileged corporations in public law. ${ }^{24}$

The new state's constitutional bill ultimately proclaimed and guaranteed the broadest freedom of conscience, religion, and public worship. ${ }^{25}$ However, the differentiation between the accepted and non-accepted churches and religious societies,

14 Zák. čl. 43/1895. See also Valeš, 2008, p. 129.

15 For example, these churches and religious societies could set up public schools. The state even gave them increased criminal-law protection, while also helping to collect church taxes, charges, and fees. Bušek, 1931, p. 326.

16 Zákon č. 11/1918 Zb. z. a nar. o zřízení samostatného státu. The attachment of Carpathian Ruthenia to the new state in 1919 contributed to religious, as well as national, diversity. One of the most important factors binding the nations together was Catholicism, since approximately $85 \%$ of the population of the republic was Catholic. Kumor and Dlugoš, 2004, p. 388.

17 Tretera, 2002, pp. 35-36; Hrabovec, 2008, p. 184.

18 Dejmek, 2004, pp. 75-83.

19 For example, in 1921, approximately 1.4 million members left the Catholic Church in Czech and Moravia. Čeplíková, 2011, pp. 64-65.

20 Pehr and Šebek, 2012, p. 46n.

21 They also protected the Slovak nation from the Hungarian state's brutal efforts to Magyarise non-Hungarian nations, which lasted until the disintegration of the Austro-Hungarian Empire. Grešková, 2008, p. 10.

22 Surmánek, 2009, p. 75.

23 Čikeš, 2010, p. 20.

24 Čeplíková, 2011, pp. 69-70.

25 §§ 121-122 ústavného zákona č. 121/1920 Zb., Ústavná listina Čekoslovenskej republiky. 
applied from the second half of $19^{\text {th }}$ century, was preserved..$^{26}$ In terms of funding, the Catholic Church was harmed to a considerable extent by the tax and land reforms, which confiscated all larger landed church estates. ${ }^{27}$ Moreover, in the whole republic the facultative civil marriages were put into practice, but the civil-law force of Church marriages were recognized, though qualified as divorceable. ${ }^{28}$ In 1925 , the parliament approved a law regulating feast days, which were considerably reduced. ${ }^{29}$ Despite strained relations between the state and churches and religious societies, a new Congrua law was issued in 1926, slightly increasing the pensions of members of the clergy. ${ }^{30}$ The situation improved considerably after 1928, when an agreement in the form of modus vivendi between Czechoslovakia and the Apostolic See delimited the boundaries of Catholic dioceses and revoked the state administration of church property, which was a constraint. ${ }^{31}$ On the other hand, the Apostolic See was reciprocally obliged to present the name of the proposed candidates for bishoprics to the government, due to the potential political reservation on the part of the state. The government set aside the goal of realising the agreement, which was only put into practice after 1935, when mutual relationships had genuinely improved. ${ }^{32}$

During the final period, conflicts appeared between the Czech and Slovak nations in the Czechoslovak Republic, which disintegrated in 1939, due to European political events and German expansion. Both the Czech nation and Moravia were annexed by the German Empire as a protectorate. ${ }^{33}$ Under threat from Hungarian expansion during the same year, a new autonomous Slovak Republic was established on the reduced territory of Slovakia, with a Catholic priest as its head. ${ }^{34} \mathrm{His}$ purpose was to govern the state in the spirit of Christian principles, in accordance

26 Wierer, 1935, p. 393.

27 Zákon č. 215/1919 Zb. z. a nar. o zabrání velkého majetku. The deteriorating relationship between the Catholic Church and the state was also related to the efforts of the Czechoslovak government to usurp the right of nomination of prelates, which was based on the ancient patronage of the Hungarian kings. Although the obligatory teaching of religion was cancelled by the constitutional act, it was taught in all Slovakian schools as a required subject. Pehr and Šebek, 2012, p. 105.

28 Zákon č. 320/1919 Zb. z. a nar. o obřadnostech smlouvy manželské, o rozluce a překážkách manželských; vykonávacie nariadenie č. 362/1919 and zákon č. 113/1924 Zb. z. a nar.

29 Bušek, 1931, p. 337.

30 Zákon č. 122/1926 Zb. z. a nar. o úpravě platů duchovenstva církví a náboženských společností státem uznaných př́ípadně recipovaných and vládne nariadenie č. 124/1928 Zb. z. a nar. o úpravě platů duchovenstva.

31 Dolinský, 1999, pp. 42-46; Halas, 2002, p. 66. In this case, the creation of a Slovak Church province with the archbishop at the head was proposed, as a way to exempt all Slovak dioceses from the jurisdiction of the ordinary residing beyond state borders. The greatest success was the removal of Slovak territory from the jurisdiction of the archbishop of Estztergom and the constitution of the Apostolic Administrature in Trnava. Tretera, 2002, pp. 39-40. Interestingly, this agreement was never formally denounced. Researchers have assumed that it ceased to exist because it was discontinued (desuetudo) due to a 'substantial change in circumstances' (rebus sic stantibus) on 1 November 1949. Suchánek, 2002, p. 219; Šmid, 2001, p. 63.

32 Dejmek, 2004, p. 85.

33 Valeš, 2008, pp. 136-137.

34 Dolinský, 1999, pp. 76-79. 
with the eternal Law of God. ${ }^{35}$ Due to the German protectionism, Slovakia had to adopt laws that expressly trespassed ius Divinum (including the limitation of personal and property freedom, the Jewish Codex, and the deportation of Jewish fellow-citizens). The constitution of 21 July 1939 declared that every citizen had the right to freely engage in religious activities, as long as these did not undermine legal regulations, the public order, or Christian morals. All churches and religious societies were recognised by the state as public-law corporations, with their own administration and property. ${ }^{36}$ Religious education was required in primary and secondary schools, carried out under state control by recognised churches and religious societies. Although no church was constitutionally preferred, the Catholic Church de facto dominated. ${ }^{37}$ With reference to state religious laws, relevant regulations, including the Congrua legislation, were taken from Czechoslovak law. ${ }^{38}$ State efforts to regulate the relationship with the Holy See included the preparation of an extensive concordat, which consisted of 35 articles and embraced all aspects of public religious life. However, the Vatican representatives ultimately recessed without setting a date to ratify the concordat. The next religious development in the territory took place during World War II, when all Church schools (from public nurseries and shelters to universities) were secularised, as instructed by the insurrectionist Slovak National Counsel. ${ }^{39}$

After the end of World War II, the Czechoslovak Republic was restored on 9 May 1945, without the territory of Carpathian Ruthenia. ${ }^{40}$ The government, in exile in London, sought to preserve the modus vivendi agreement of 1928, establishing correct relationships between churches, religious societies, and the state at the beginning of the post-war period. However, communists in both countries struggled to obtain state power and finally succeeded in 1948, by means of a putsch. Despite the freedom of religion and conscience enshrined in the Constitution of the People's Democratic Republic in 1948 ( $\S 15-17$ ), a completely new platform was built that year for the next development in the relationship between the state and churches and religious societies. ${ }^{41}$ The most difficult measures were imposed against the Catholic Church,

35 For example, approximately one-fifth of the members of the Assembly of the Slovak Republic were Catholic clergymen. Moravčíková, 2003, p. 101. Moreover, symbols from earlier historical periods were banned by the government, including the crown of St. Stephen. Hetényi and Ivanič, 2010, p. $340 .{ }^{28}$ Furthermore, the Ministry of Education and National Culture decreed that every classroom had to display the sign of the cross as a symbol of Slovak Christian culture. Both before and after class, schoolchildren had to say a prayer. Garek, 2010, p. 223.

36 Kamenec, 2011, pp. 175-192.

37 Kumor and Dlugoš, 2004, pp. 394-396.

38 Čikeš, 2010, pp. 28-29.

39 Nariadenie Slovenskej národnej rady č. 5/1944 Zb. n. See also Londáková, 2008, p. 336n; Dolinský, 1999, pp. 95-96.

40 The loss of approximately one million highly religious people diminished the status of believers in the Czechoslovak post-war state. Tretera, 2002, p. 41.

41 Of course, the constitution did not specify the legal status of churches and religious societies. For a short period, they therefore retained the status of privileged, autonomous corporations. Kindl, 1998, pp. 311-313. 
which more than $70 \%$ of the Czechoslovak population belonged to, as it enjoyed a very special position in Slovak territory. ${ }^{42}$ These measures consisted especially in the restriction of the activities of bishops, their isolation from clergy, the establishment of new state-controlled Catholic Action and the individual State Office for the Church Matters, the support of clergymen properly performing their "socialistic duties", the intervention to the activities of Catholic institutions and print, limiting the impacts of the Apostolic See and the effort to constitute an independent national particular church. ${ }^{43}$ These politics was put into practice in 1949, when diplomatic relations with the Apostolic See were interrupted and several anti-ecclesiastical laws were issued. ${ }^{44}$ Churches and religious societies were viewed as institutions opposed to the state, or-to be more precise-as ideological or governmental rivals. ${ }^{45}$ The state also set out to secularise almost all of the property owned by churches and religious societies, apart from sacral objects. In this way, religious property was brought under state financial and political control. ${ }^{46}$ The State Office for Church Matters played the most important role, supervising all church activities directly or indirectly. ${ }^{47}$ The establishment of this office meant that the state never had to think about separating church and state. The communists believed that such a separation would increase the social influence of churches and religious societies and prevent the state from interfering with their internal affairs. ${ }^{48}$

Economic surveillance deepened after the establishment of Law No. 218/1949, through which the state regulated the economic affairs of churches and religious societies. The regime obligated itself to pay the personal salaries of clergy belonging to recognised churches and religious societies, on condition that they obtained state authorisation, awarded only to Czechoslovak citizens recognised for their reliability and probity $(\S 1) .^{49}$ Through this law, churches and religious bodies ceased to be public-law subjects and became completely dependent on state, both politically and

42 Pešek and Barnovský, 1999, p. 35n.

43 Balík and Hanuš, 2007, p. 111n; Pešek and Barnovský, 1997, p. 61n; Vaško, 2004, p. 113n.

44 Casaroli, 2001, p. 129n.

45 Fiala and Hanuš, 2001, p. 9n. During the communist period, the Czechoslovak Republic resembled an 'à rebours' theocratic state, which promoted the ideology of atheism in response to the religion and faith of classical theocratic states. Tretera, 2002, p. 12; Campenhausen, 2002, p. 453; Doe, 2011, pp. 9 and 142.

46 Of course, the regime primarily confiscated church property. The rest was then qualified as a private ownership (the third form of socialistic ownership). Juran, 2008, p. 12; Hlavová, 2008, p. 356n.

47 In addition, the Slovak Office for Church Matters was responsible for normative, directive, and supervisory tasks. It intervened in the administration of churches and religious societies, protected church monuments, resolved salary issues involving clergymen, teachers, and employees of theological faculties, provided religious schooling, and expertly appraised churches and religious prints and publications. Pešek and Barnovský, 1997, pp. 10-11, 84-85, 98-99.

48 Čikeš, 2010, p. 32.

$49 \S 1$ zákona č. 218/1949 Zb. The anti-ecclesiastical laws were enacted through five statutory orders, continually enforced against individual churches and religious societies. Balík and Hanuš, 2007, p. 26n; Vaško, 2004, p. 160n. 
economically. ${ }^{50}$ Next, the education system was secularised and a new atheistic and Marxist didactical program was brought in. ${ }^{51}$ Religion could be taught only by clergyman with the agreement of the state. Concerning marriages, in the whole territory of Czechoslovakia the obligatory civil form of its contracting was decreed that had to precede the eventual marriage before the clergyman of church or religious society. ${ }^{52}$ In 1950, most members of male religious orders were discharged and interned during 'Operation K'; later, female members of religious orders were subjected to the same punishment in 'Operation R..53 In 1960, a new constitution was passed, which renamed the state the 'Czechoslovak Socialist Republic', while once again formally guaranteeing the freedom of religious belief. ${ }^{54}$ However, the situation did not ease in Czechoslovakia until relatively recently, especially after Alexander Dubček (19681969) became the general secretary of the Communist Party of Czechoslovakia and tried to introduce various democratic changes to society. ${ }^{55}$ The Prague Spring (1968) revival movement adopted those ideas and helped to entrench many positive elements in political, social, and religious life. ${ }^{56}$ All of the processes of democratisation ended on 21 August 1968, when the country was occupied by the Warsaw Pact armies. Then the so-called normalisation process (1968-1989) caused the status of churches and religious societies to deteriorate further. ${ }^{57}$ Subsequently, the government interfered to a significant extent with religious life, limiting the number of students (numerus clausus) in seminaries, depriving clergymen of state approval, and intimidating members of the laity through state security (ŠtB) activities. ${ }^{58}$

When more liberal politics were introduced to the Soviet Union, the situation in Czechoslovakia also improved. The fall of communism and the establishment of democratic changes in society ultimately fell into alignment after the events of the 17 November 1989 'Velvet Revolution', which led to a revision of the constitution and changes to the state name, first to the Czechoslovak Federative Republic and then to the Czech and Slovak Federative Republic. After the Communist Party of Czechoslovakia lost its political monopoly, ${ }^{59}$ diplomatic relations were established

50 The derogatory clause $\S 14$ abrogated all of the rules that had previously regulated the legal status of churches and religious societies. Tretera, 2002, p. 49.

51 Horák, 2011, pp. 52, 65 and 149.

52 Family-law violations were criminally prosecuted through sanctions imposed on the content of the criminal acts. § 211 trestného zákona č. 140/1961 Zb.

53 Chenaux, 2012, pp. 77-79. None of the religious orders could dispose of novices; violating this prohibition constituted the criminal act of obstructing the supervision of churches and religious societies. § 178 trestného zákona č. 140/1961 Zb. See also Pešek and Barnovský, 1997, p. 161n.

54 Čl. 32 Ústavného zákona č. 100/1960 Zb, Ústava Československej socialistickej republiky. Along with this vague provision, it also declared that no one could refuse a civic duty prescribed by law on grounds of religious belief or conviction. Tretera, 2002, p. 52.

55 Pešek and Barnovský, 1999, p. 165n.

56 One very positive consequence was the restoration of the Greek Catholic Church that had been dissolved and violently joined to the Orthodox Church in 1950. Pešek and Barnovský, 1997, p. 240n.

57 Balík and Hanuš, 2007, p. 91.

58 Pešek and Barnovský, 2004, p. 123.

59 Šimulčík, 1999, p. 33n. 
with the Apostolic See and the previously illegal male and female religious orders were officially restored, in accordance with Federal Assembly Laws nos. 298/1990 Zb. and 338/1991 Zb. Several badly damaged properties were returned to churches and religious bodies during the first period of restitution. ${ }^{60}$ However, the state continued to supervise churches and religious societies de iure until 1991, when Law No. 308/1991 Zb. on the freedom of religious belief and the status of churches and religious societies (still valid in Slovakia) recognised them as individual corporations with the right to self-administration. This development genuinely improved the relationship between the state and churches and religious societies, ultimately achieving a status that was completely comparable with that of other democratic states and guaranteed external and internal autonomy. ${ }^{61}$ The state recognised the important role played by religious bodies in forming society and henceforth supported them, within a framework that included certain forms of funding for clergymen's salaries, church funds, and partially even headquarters. Since churches and religious societies ran church schools and operated various social and charitable activities, public resources could be used even for these purposes. ${ }^{62}$

Democratic development continued after the formation of the Slovak Republic on 1 January 1993, establishing a new independent state against the backdrop of various misunderstandings between Czech and Slovak politicians. The new state immediately established diplomatic relations with the Apostolic See, reflecting both international standards and historical traditions. Simultaneously, the restitution of real estate as well as movable estates continued, in accordance with Law No. 282/1993 Z.z.; this mitigated some property injustices suffered by churches and religious societies (the second period of restitutions). One example of Vatican diplomacy was the Basic treaty between the Slovak Republic and the Holy See in 2001. In 2004, the Slovak Republic joined the European Union, confirming its democratic stance and wholesale defence of human rights. ${ }^{63}$ In 2005, the final period of restitutions took place; in accordance with the Law No. 161/2005 Z.z., several properties were returned to churches and religious societies. At the time of the 2011 census, religious affiliations in the Slovak Republic were as follows: $65.8 \%$ of citizens selfidentified as Catholics, $62 \%$ as Latin Church members, 3.8\% as Greek Catholics),

60 Halas, 2002, p. 51n. The reality showed that constructive dialogue between the state and churches and religious societies was the best way to resolve the problems and tensions of society. Čeplíková, 2011, p. 111. Alongside the moral and legal satisfaction of having the existence of religious orders accepted without special permission from the state, they also received compensation for lost property. Kalný, 1995, p. 23n.

61 Kumor and Dlugoš, 2004, pp. 472-473.

62 Through a system of grants, the Ministry of Culture of the Slovak Republic began to provide funding, so that they could renovate and revitalise national cultural monuments. Čikeš, 2010, p. 51.

63 It is worth remembering that the European Union does not have a unified view on questions of religious freedom or the church-state relationship. Every member state resolves these issues in accordance with its own cultural-historical traditions. See for example Deklarácia č. 11 o postavení cirkví a náboženských spoločností a nenáboženských organizácií, tvoriaca prílohu Záverečného aktu Amsterdamskej zmluvy. See also Ferrari, 1995, p. 149. 
5.9\% as Evangelicals, and $13.4 \%$ as non-religious. Compared to the previous census, the population self-identifying as religious rose by $11.3 \%$, from $75.8 \%$ to $84.1 \%$. It is therefore clear that religious beliefs have not lost their significance in society. Instead, they remain one of the most important factors influencing everyday social reality. ${ }^{64}$ This development, including contemporary adjustment of Slovak society, may be denoted as the main factors for the non-existence of conflicts on the account of the use of religious symbols in the public sphere.

\section{Axiological and constitutional foundations and sources of state religious law}

Slovakia does not actually have a serious problem with the use of religious symbols in the public sphere. This study will explain the fundamental axiological and constitutional scope of the state religious laws that enable this status. The first and most important determinative factor is the historical development of Slovakia. ${ }^{65}$ Especially the communist period imposed that after the fall of this regime the state urged to meet the needs of churches and religious societies, which were prosecuted on a long-term basis, and that led to several steps to the majority of the countries unknown. The proclaimed axiological setting of the Slovak legal system can also be deduced from the preamble to the constitution, which reflects 'the Cyrilo-Methodian spiritual heritage and the historical legacy of the Great Moravian Empire. ${ }^{66}$ On the other hand, the Slovak Republic keeps the formal character of a religiously neutral state, what is evident from the fact that no rights or duties enforceable by the public bodies result from the moral or legal system of any church or religious society ${ }^{67}$ Of course, the state simultaneously recognises traditional democratic standards, guaranteeing private, as well as corporate (institutional) religious freedom. Although the state still funds the material needs of churches and religious societies, present circumstances indicate that the separation of church and state will not be discussed during the next few years. ${ }^{68}$ Concerning the use of religious symbols in the public sphere, as mentioned several times, it is not pertracted in Slovakia. Most

64 At the same time, the number of people with no affiliation to a church or religious society increased by $3.16 \%$ to $12.98 \%$. The public discussion of the new model of church and religious-society financing may have played a role in this, as well as contiguous campaigns denoting those contributions as misused. Moravčíková, 2003, p. 98.

65 Campenhausen, 1994, p. 47.

66 Preambula ústavného zákona č. 460/1992 Zb., Ústava Slovenskej republiky. See also Šústová Drelová, 2019, p. 388.

67 čl. 1, ods. 1 ústavného zákona č. 460/1992 Zb., Ústava Slovenskej republiky.

68 However, some liberal political parties sometimes formally raise these endeavors, and the present situation is no different. See for example: https://www.noviny.sk/554769-sulik-odluka-cirkvi-odstatu-je-pre-sas-dolezita-strana-sa-jej-bude-venovat-nadalej. 
legal sources treat this topic as unimportant, assuming that potential problems will be resolved through court decision-making, based on constitutional rules and laws, the laws and legislative rules of the Slovak Republic, or binding European laws. As pointed out, it is not possible for them to apply any other rule and that was also declared by the Constitutional Court of the Slovak Republic. ${ }^{69}$ The Constitution on the other hand expressly guarantees the right of every individual to manifest his or her religion or faith; it can be deduced that this right includes the right to manifest a religion or faith through religious symbols..$^{70}$ Concerning their use in the public sphere, all of the relevant legal sources are silent. ${ }^{71}$

Of course, another important factor has been the developing political situation. Even Slovak politicians have frequently used the so-called religious card to make political capital. This generally damages the relationship between the state and churches and religious societies, eventually creating negative perceptions among non-religious people. Even in Slovakia's recent history, some politicians have been consistently helpful, especially towards the dominant Catholic Church, in order to maximise their own political capital with a majority of Slovak citizens. In 2006, negotiations on the highly anticipated conscientious objection treaty between the Slovak Republic and the Holy See and the agreement between the Slovak Republic and registered churches and religious societies concerning the same topic, caused the government coalition to disintegrate, resulting in snap elections. ${ }^{72}$ This showed that the ideological diversity and incompatible worldviews of liberal politicians could, even in the $21^{\text {st }}$ century, lead to something like a civil culture war. ${ }^{73}$ Religious issues in Slovakia are distinctively emotional and members of the public pay attention to them. However, in general, we may allege that from those times politicians essentially shun these topics, as well as the extreme opinions in the field of religious belief of individuals. ${ }^{74}$ Of course, once the needs of Catholic Church were met, equivalent treatment was officially requested

69 Nález Ústavného súdu Slovenskej republiky sp. zn. III. US 64/00.

70 Čl. 24, ods. 2 ústavného zákona č. 460/1992 Zb., Ústava Slovenskej republiky.

71 The fourth section of this article indeed declares that the conditions of exercising these rights can be limited by law only in cases when it is necessary for a democratic society to protect public order, health, morality, or the rights and freedoms of others. Čl. 24, ods. 4 ústavného zákona č. 460/1992 Zb.

72 Čl. 7 Základnej zmluvy medzi Slovenskou republikou a Svätou stolicou vyhlásenej pod číslom 326/2001 Z.z. ako oznámenie Ministerstva zahraničných vecí and čl. 7 Dohody medzi Slovenskou republikou a registrovanými cirkvami a náboženskými spoločnostami publikovanej pod č. 250/2002 Z.z. See also Čeplíková, 2011, p. 216.

73 Čikeš, 2010, pp. 72-73.

74 Liberal politicians revealed their fundamental attitudes when discussing the Basic treaty between the Slovak Republic and the Holy See. They disrupted the Slovak Republic's plan to align its legal system with the text of the treaty and refused the declaration of the contracting parties that only the heterosexual, monogamous family is the basis for a healthy society and worthy of protection. Slovensko, 2001. Súhrnná správa o stave spoločnosti, 2001, p. 130. The actual situation indeed arouses serious ideological dissimilarities in the opinions of liberal and conservative politicians. While the former began to argue about the separation of church and state, the latter repeatedly discuss the issue of regulating conscientious objection through an individual law. Their efforts are related to the visit of Pope Francis (2013-) to Slovakia. See: https://bit.ly/3okkyWZ. 
by non-Catholic churches and religious societies and the state automatically complied, in accordance with the principle of parity. ${ }^{75}$ In contrast to other European countries, according to the secretaire of the Central Union of Jewish Religious Communities, Slovakia is 'a paradise'. ${ }^{76}$ It is therefore not surprising that any conflict between the churches and religious societies in the Slovak Republic is actual and their relationships are more than excellent. An important aspect of the non-existence of causes relating to the problems of religious symbols in the public sphere is also connected with the attitude of Slovak politics refusing mandatory migrant quotas, evoking in the minds of the majority of the population Islam and the fear of possible terrorist attacks.

The state religious law of the Slovak Republic is included in the provisions of several enactments of various types and of legal power. First and foremost, it is necessary to distinguish between internal state religious law, international and contractual state religious law, and European religious law. Explaining this structure makes it easier to understand the relationships between the state and churches and religious societies, as well as the regulations used to solve potential problems. Internal state regulations are contained in the normative legal acts of Slovak Republic government bodies (the constitution, constitutional laws, and other laws), which regulate the general rights and duties of respondents. ${ }^{77}$ More detailed regulations may be found in the statutory orders of the government of the Slovak Republic and in the ordinances of ministries and other central state-administration institutions. Specific legal sources include the findings of the Constitutional Court of the Slovak Republic, in contrast to the internal normative acts of ministries and central administrative bodies, including instructions, directives, edicts, and provisions. Above all, international and contractual state religious law represents treaties with the Holy See as international laws that does not have priority over the laws of the Slovak Republic. ${ }^{78}$ Multilateral treaties that regulate issues involving religious freedom, via the 1950 European Convention on Human Rights (as amended through additional protocols) and the 1966 International Covenant on Civil and Political Rights are prioritised sources, in relation to the laws of the Slovak Republic. ${ }^{79}$ Individual statutes have also

75 Tretera, 2002, p. 14.

76 Within this context, it is important to note that the Slovak Republic did not exaggerate the protection offered to small and (in the long term) established churches and religious societies. I am grateful to my esteemed colleague, Prof. JUDr. Matúš Nemec, PhD., for bringing this to my attention.

77 Čeplíková, 2011, p. 20. Internal and moral regulations are not legal sources in the Slovak Republic, even though Christian morals and other principles are expressed via facti in certain provisions of state law (for example in relation to the criminal acts of homicide, theft, and bigamy and the legal regulation of public holidays). Baláž, 2000, p. 62n.

78 Čl. 7, ods. 4 ústavného zákona č. 460/1992 Zb., Ústava Slovenskej republiky.

79 These international agreements fall under the heading of international treaties on human rights and fundamental freedoms, respectively international treaties that do not need laws for their enforcement or international laws constituting the direct rights and duties of natural persons and corporate entities, as decreed by law. Čl. 7, ods. 5 ústavného zákona č. 460/1992 Zb., Ústava Slovenskej republiky. The European Convention on Human Rights is exceptional because it is applied directly to the legal systems of member states, unlike universal agreements on human rights. Moravčíková, 2003, p. 106. 
internal agreements between state and non-Catholic churches and religious societies. Due to their subjectivity, these agreements are not ranked among the rules of international law. ${ }^{80}$ The legal sources do not include various declarations officially sanctioned by the United Nations or European Parliament as recommendations or appeals. ${ }^{81}$ However, the 1981 UN Declaration on the Elimination of All Forms of Intolerance and of Discrimination Based on Religion or Belief encourages all member states to ensure that their citizens can exercise their subjective rights. ${ }^{82}$

In various ways, European state religious law is positioned as supranational law. The European Union has explained its decision to protect individual religious freedom by referring to art. 6, sect. 2 of the Treaty on the European Union and the importance of respecting the human rights guaranteed by the European Convention on Human Rights. ${ }^{83}$ In relation to corporate religious freedom, art. 17, sect. 1 of the Treaty on the European Union emphasises the fact that the European Union respects and does not interfere with the status of churches and religious communities in member states. ${ }^{84}$ The significance of these treaties is evident because they take precedence over the laws of the Slovak Republic. ${ }^{85}$ Especially when discussing forms of regulation, it is difficult to speak about European state religious law, because the primary sources of European Union law, with the exception of the two provisions mentioned above, pay no attention to institutional religious freedom. ${ }^{86}$ As previously mentioned, the section on community law represents, in accordance with the 1950 European Convention on Human Rights, the regulation of individual religious freedom. The European Union first and foremost defines certain principles that bind individual member states directly or indirectly. ${ }^{87}$ Religious freedom, according to European supranational standards, is clearly protected by secondary sources of

80 § 4, ods. 5 zákona č. 308/1991 Zb. o slobode náboženskej viery a postavení cirkví a náboženských spoločností.

81 Within this context, one example is the 1948 Declaration on Religious Liberty of the World Council of Churches, considered to be the predecessor of church-state agreements at the international or supranational level (especially the Universal Declaration of Human Rights). See also Hanuš, 2002, p. $57 \mathrm{n}$.

82 This declaration was the international community's response to the widespread denial of religious freedom worldwide and the avoidance of UN responsibilities. It appealed to individual states to prevent the proliferation of religious intolerance by enacting effective laws. Davala, 2013, p. $118^{24}$.

83 Witte and Green, 2012.

84 The same approach was also adopted in art. 11 of the Declaration on the Status of Churches and Non-Confessional Organisations, part of the Treaty of Amsterdam, which supplanted the Treaty on the European Union. Doe, 2011, p. 29.

85 Čl. 7, ods. 2 ústavného zákona č. 460/1992 Zb., Ústava Slovenskej republiky.

86 This is not surprising because the primary focus of European integration was economics and the protection of human rights, not institutions. Kaiser and Varsori, 2010, p. 140.

87 We may mention especially following principles: the principle of neutrality; tolerance of all religions and worldviews; parity (maintaining the same approach towards all religious organisations); loyalty to the constitutional systems of members states, while rejecting the one-sided adjustment of state religious systems to these models; European Union non-involvement in state religious affairs; and EU proportionality (not overstepping its role beyond the steps needed to achieve its objectives). See also Taylor, 2005. 
European Union law, including judgments of the Court of Justice of the European Union, principles of the European Community, and European-international standards adjudicated by the European Court for Human Rights, which uses the European Convention on Human Rights to decide cases related to individual religious freedom, in accordance with art. 9 of that convention. ${ }^{88}$ It is important to note that the effects of the judicial decisions in cases involving citizens in the religious matters must be transformed to the legal system of the Slovak Republic. ${ }^{89}$

\section{Model of relations between the state and churches and religious societies}

Throughout history, several models of state-church relations changed in Slovak territory. Due to the high religiosity of the Slovaks, no separation of church and state ever took place. By contrast, most regimes have sought to collaborate with religious institutions to satisfy citizens and secure good relationships, especially with the dominant Catholic Church. During the First Slovak Republic, there was an attempt to privilege the Catholic Church; by contrast, the communist regime replaced mainstream religions with its own non-religious cult, which had its own forms and symbolic manifestations. The new democratic regime strove to attain perfect cooperation between the state and churches and religious societies. Although the Slovak state is now considered secular, there is still a strong, collaborative relationship between state power and individual churches and religious societies. It is therefore appropriate to speak about a cooperative, coordinated, or conventional model. ${ }^{90}$ As is generally known, such models typically produce harmonious cooperation and freedom of religion, while respecting the external and internal autonomy of churches and

88 Of interest is the critical stance of foreign studies towards this institution's controversial decision-making in the field of freedom of thought, conscience, and religion. It is generally accused of inconsistency and failing to settle controversial and ambiguous questions. Evans, 2003; Taylor, 2005. It is worth mentioning the view that claims of court protection and the relocation of human-rights protection from political instruments to the courts paradoxically made them more complicated and confused. Barány, 2007, p. 66.

89 Klíma, 2009, p. 76.

90 Madleňáková, 2010, p. 8. We consider this division even though some publications consider wrong to classify states as separationist and cooperative, since the two are continually converging. Such authors typically argue that the division reflects a formal view of institutional adjustments to these relationships, without really considering the actual course of events. Even the classification of the models of relations between the state and religious societies according to the status of their corporate entities of private or public law is problematic. For example, in Greece and Germany, some churches have the status of corporate entities in public law; in France and the Netherlands, the relevant law is private. Due to this division, it is impossible to include these countries in the same group. Čikeš, 2010, p. 81; Kiderlen, 1993, p. 104. 
religious societies. ${ }^{91}$ Since the state regulates the legal status of all churches and religious societies equally, despite the domination of the Catholic Church, the principle of religious parity is also accepted in Slovakia. ${ }^{92}$

Art. 1 of the Constitution presents the Slovak Republic as secular state, which is not bound or affiliated to any religion. ${ }^{93}$ As an established democratic state, however, its constitution provides a full guarantee of individual religious freedom (freedom of thought, conscience, religion, and faith) as a fundamental human right, while also respecting the right of every individual to be non-religious. ${ }^{94}$ Churches and religious societies are allowed to act in public, as well as in private, offering their services to society. ${ }^{95}$ Within this context, the spheres of both legally perfect societies (societates iuridice perfectae) often meet and overlap, since they relate to the same people, as citizens of the state and members of churches and religious societies. ${ }^{96}$ When it comes to institutional religious freedom, or the freedom of religious institutions to engage in public social activities, Slovakia is a cooperative (coordinative) state. ${ }^{97}$ Although the Slovak Republic is not bound to any religion, it is not neutral. Several Slovak legal sources directly or indirectly note the great importance of religion in underpinning education and the formation of human beings. Churches and religious societies provide activities that the state would find difficult or impossible to offer..$^{98}$ The principle of parity applied to relationships with churches and religious societies in Slovakia is partially modified through the guaranteed opportunity to achieve public-law status after meeting certain conditions. ${ }^{99}$ The registration of religious organisations leads some experts to speak of 'two-step parity'. Through the process of registration, the state formally recognises each organisation as a spiritually oriented entity with its own stable religious doctrine and membership and a functional organisational structure. ${ }^{100}$ It is clear that the Slovak Republic respects their particular

91 Čikeš, 2010, p. 14.

92 § 4, ods. 2 zákona č. 394/2000 Z.z. See also Tretera, 2002, p. 14.

93 Čl. 1, ods. 1 and 2 zákona č. 308/1991 Zb. o slobode náboženskej viery a postavení cirkví a náboženských spoločností. See also Campenhausen, 1994, p. 78.

94 Wolterstorff, 2012, p. 42n.

95 In this connection, it is appropriate to mention that people consider churches and religious societies to be highly trustworthy. Čeplíková, 2011, p. 227.

96 In accordance with the principle of territoriality, state power impacts everyone in state territory. By contrast, churches and religious societies exert spiritual power only over their members. They must therefore accept the principles of the rule of law, especially the sovereignty of law. Hrdina, 2004, p. 60.

97 State non-identification with churches and religious societies helps to preserve the ideological neutrality of the state, while respecting the right of every individual to have freedom of religion. Moreover, the state provides the legislative framework for the corporate functioning of religious organisations. Čikeš, 2010, pp. 11, 14.

98 Úvod Základnej zmluvy medzi Slovenskou republikou a Svätou stolicou vyhlásenej pod číslom 326/2001 Z.z. ako oznámenie Ministerstva zahraničných vecí and Úvod Dohody medzi Slovenskou republikou a registrovanými cirkvami a náboženskými spoločnostami publikovanej pod č. 250/2002 Z.z. See also Tretera, 2002, pp. 14-16.

99 Čeplíková, 2011, p. 32.

100 Nemec, 1997, p. 21. 
status as subjects sui generis, not identical to any non-governmental subject. ${ }^{101}$ Undergoing registration is also a condition for acquiring material subventions from the state. $^{102}$

In addition to claiming a state subsidy for clearly specified purposes, registered churches and religious societies also have the right to carry out some official acts as public-law subjects. Their clergymen, as public officers, have public-law powers, such as the power to conduct a marriage. ${ }^{103}$ In addition, they can set up their own organisations, including schools, hospitals, and various types of charitable institutions. Once legally specified conditions have been met, they also have the right to minister to believers in public facilities, such as hospitals, jails, and universities. They have some access to public media and can teach religion in public schools. ${ }^{104}$ To achieve better cooperation, registered churches and religious societies make individual contracts with the Slovak Republic, such as an international-law treaty with the Holy See, in the case of the Catholic Church, or internal agreements, in the case of nonCatholic churches and religious societies. Some experts agree that the church-state relationship in Slovakia is midway between a strict separation of church and state and an established church. ${ }^{105}$ All religious institutions are established and enjoy individual prerogatives, but all are governed by the state law. ${ }^{106}$ Returning to the topic of this paper, the state guarantees citizens the right to manifest their religious beliefs externally; no relevant legal sources prohibit the use of religious symbols in the public sphere, as is for example the case in France under the 2004 law on secularity and conspicuous religious symbols. ${ }^{107}$

\section{Constitutional guarantees of freedom of conscience and religion}

The Constitution of the Slovak Republic protects freedom of thought, conscience, and religion as fundamental human rights that pertain to every citizen, regardless of his or her nationality, race, skin colour, religion, political or other

101 See also Duffar, 1995, p. 152.

102 On the other hand, the Slovak Republic accepts churches and religious societies that do not meet the conditions of registration (in particular, the legal minimum of 50,000 members). Such groups include the Jewish religious community and smaller Christian denominations. Based on this legal requirement, the Slovak Republic is often described as having the most severe registration law in the European Union. Zákon č. 39/2017 Z.z. See also Řepová, 2004, p. 95.

103 Čikeš, 2010, p. 11.

104 Čl. 24, ods. 2 ústavného zákona č. 460/1992 Zb., Ústava Slovenskej republiky.

105 If there were no financial cohesion between the state and churches and religious societies, we could perhaps speak of the separation of church and state. McCrea, 2014, pp. 8-9.

106 Moravčíková, 2003, p. 105.

107 See also Doe, 2011, pp. 34-35, 146, 199 and 205; Evans, 2012, p. 188n. 
convictions, social origin, education, financial or social status, genetic makeup, or other individual attributes. ${ }^{108}$ Essentially it acknowledges the character of natural law, which relates to the essence of every individual as a human being. ${ }^{109}$ This approach was adopted after the fall of the communist regime, when Constitutional Law No. 23/1991 Zb. was enacted as a Bill of fundamental rights and freedoms. This legal source, which remains a foundation stone of the legal system of the Slovak Republic, provides a fundamental legal platform for special legal regulations in this area. ${ }^{110}$ Its importance is reflected in both the Constitution of the Slovak Republic and Law No. 308/1991 Zb. on freedom of religious belief and the status of churches and religious societies. ${ }^{111}$ The sources mentioned here do not constitute these rights, but simply declare them, asserting that their recognition, declaration, and confirmation are inalienable, vested, and inviolable. ${ }^{112}$ Art. 15, sect. 1 of the bill states that that 'Freedom of thought, conscience and religion is guaranteed. Everyone has the right to change his religion or faith or be unreligious'. ${ }^{113}$ This paper draws on art. 16 in particular, as it establishes the point that everyone has the right to manifest freely his or her own religion or faith, either alone or with others, privately or publicly, through worship, teaching, religious acts, or the observation of religious ceremonies. Sect. 2 of this article is

108 Čeplíková, 2011, p. 5. For example, the Basic treaty between the Slovak Republic and the Holy See (art. 7) guarantees everyone the right to conscientious objection, based on the doctrinal and moral maxims of the Catholic Church, assuming an international-law treaty on the extent and conditions of this right in Slovakia. Čl. 7 Základnej zmluvy medzi Slovenskou republikou a Svätou stolicou vyhlásenej pod číslom 326/2001 Z.z. ako oznámenie Ministerstva zahraničných vecí. See also Moravčíková, 2007.

109 See also Sousedík, 2010, p. 40n. The term 'freedom' is used to indicate human rights that must be absolutely secured and guaranteed by the state. Human rights have a broader meaning here, since they belong to every individual, regardless of whether any law regulates or guarantees them. The term 'fundamental freedom' refers to the constitutionally embodied and legally guaranteed opportunity to realise or not realise an undetermined and unspecified activity. Madleňáková, 2010, pp. 12 and 35.

110 Svák and Cibulka, 2006, p. 169n.

111 Although the Bill of fundamental rights and freedoms was enacted by the Czechoslovak Federation, it still provides the basic rules of state religious law, regulating questions of freedom, religion and conscience, as well as the status of churches and religious societies and their relations with the state. This law meets the conditions for the statute specified in art. 152, sect. 1 of the Constitution of the Slovak Republic. As a matter of interest, this bill was accepted in the Czech Republic, but only with the force of law; it was never incorporated into the text of the Constitution itself. Ústavný zákon č. 4/1993 Sb. o opatřeních souvisejících se zánikem České a Slovenské Federativní Republiky. See also Koudelka and Šimíček, 1996, p. 176.

112 Čl. 1 ústavného zákona č. 23/1991 Zb., ktorým sa uvádza Listina základných práv a slobôd. The legislature was mainly inspired by the standard documents of international law, including the Universal Declaration of Human Rights, the International Covenant on Civil and Political Rights, and the European Convention on Human Rights. Legislators also reflected on the constitutional traditions of Germany and the United States. Several experts have even mentioned natural-law theories, including the Christian religious tradition. Madleňáková, 2010, p. 28; Pavlíček, 2004, p. 41.

113 Čl. 15, ods. 1 ústavného zákona č. 23/1991 Zb., ktorým sa uvádza Listina základných práv a slobôd. 
particularly important in shaping the mutual relationships between the state and churches and religious societies, guaranteeing their autonomy and independence in internal matters as follows: 'Churches and religious societies administer their own matters, especially by establishing their own institutions, appointing clergymen and founding religious or other church institutions independently of public bodies'. As is typical in democratic societies, these rights can only be restricted under legal authority to protect public safety, the social order, health, morality, and the rights and freedoms of others. ${ }^{114}$

As mentioned, the constitution first and foremost refers to the 'Cyrilo-Methodian spiritual heritage and historical legacy of the Great Moravian Empire'. ${ }^{115}$ Art 12, sect. 1, following the Bill of fundamental rights and freedoms, declares that 'People are free and equal in their dignity and rights. Fundamental rights and freedoms are vested, inalienable, imprescriptible and irrevocable'. While this statement refers to all fundamental rights and freedoms, sect. 2 of this article declares that: 'Fundamental rights and freedoms are guaranteed in the territory of the Slovak Republic to everyone, regardless of sex, race, colour of skin, language, faith or religion, political or other thoughts, national or social origin, membership of a nationality or ethnic group, property, birth or other status'. ${ }^{116}$ Again, following the Bill of fundamental rights and freedoms, arts. 14-25 of the constitution accept that fundamental human rights and freedoms are connected with the essence of human beings, their dignity, and the reverence due to them as human beings. The subjects of public power must proceed always and only in accordance with the constitution, in its bounds and to its extent, as constituted by law. ${ }^{117}$ Therefore, every individual who is the subject of fundamental rights and freedom may, in accordance with the principle that 'everything which is not forbidden is allowed', do anything that is not prohibited by law; likewise, no one may be forced to do anything that is not ordered by law. ${ }^{118}$ Even individual duties are legally binding only to the extent that fundamental rights and freedoms are observed. ${ }^{119}$ They can only be implemented on legally justified occasions, after meeting all legal conditions and completing all forms and proceedings. ${ }^{120}$ Of course, all fundamental rights and freedoms are protected to that extent and range, unless and until they restrain or deny the rights and freedoms of others. The subjects of fundamental human rights and freedoms are referred to in different ways. The broadest term under natural

114 Čl. 24, ods. 4 ústavného zákona č. 460/1992 Zb., Ústava Slovenskej republiky.

115 Preambula ústavného zákona č. 460/1992 Zb., Ústava Slovenskej republiky.

116 Čl. 12, ods. 1 and 2 ústavného zákona č. 460/1992 Zb., Ústava Slovenskej republiky.

117 Čl. 2, ods. 2 ústavného zákona č. 23/1991 Zb., ktorým sa uvádza Listina základných práv a slobôd.

118 Čl. 2, ods. 3 ústavného zákona č. 23/1991 Zb., ktorým sa uvádza Listina základných práv a slobôd.

119 Čl. 13, ods. 1 ústavného zákona č. 460/1992 Zb., Ústava Slovenskej republiky.

120 Čl. 13, ods. 2 ústavného zákona č. 460/1992 Zb., Ústava Slovenskej republiky. 
law is 'everyone'; this term is used even to refer to freedom of thought, conscience, and religious belief or faith. ${ }^{121}$

In state religious law, art. 24 of the Constitution of the Slovak Republic guarantees freedom of thought, conscience, religious belief, and faith. Concretely, it states that 'Freedom of thought, conscience, religious belief and faith are guaranteed'. Neither the constitution, nor any other legal source, specifies these terms and that leads to the deduction they can be analysed by the theory of law, sociology, psychology, ethics, or theology. ${ }^{122}$ A more detailed analysis suggests that the subject this article protects is not just religious freedom, but the spiritual and intellectual freedom of every human being, whether a believer or an atheist. The churches and religious societies may be then designated as main institutional guarantees of these freedoms. ${ }^{123}$ The second sentence of art. 24, sect. 1 suggests that an individual's right to change his or her religious belief or faith is an absolute right pertaining to the forum internum. ${ }^{124}$ No one may be at the same time forced to change his or her religious belief or faith or to have any religious belief or faith at all. ${ }^{125}$ Of course, these rights would have no real value, if their public and external manifestation would not be legally guaranteed. The last sentence of sect. 1 therefore declares that 'Everyone has a right to manifest his thinking publicly', while sect. 2 develops this idea further by saying that 'Everyone has a right to freely manifest his or her religion or faith either alone or with others, privately or publicly, through worship, religious activities, observing ceremonies or participating in education. ${ }^{126}$ No one can be compelled to manifest a particular belief in public, as is the case with freedom of thought, conscience, religious belief, and faith. ${ }^{127}$ The main difference between these rights is the fact that freedom of manifestation can be subject to legal limitations for legitimate reasons. ${ }^{128}$

With reference to institutional religious freedom, art. 1 of the Constitution of the Slovak Republic implicitly declares the principle of pluralism in the spiritual arena, declaring that the 'Slovak Republic is sovereign, democratic and legally consistent state. It is not bound to any ideology or religion'. The legal system of the Slovak Republic clearly refuses to privilege any ideology or religion; in fact, it prohibits the preferential treatment of any church or religious society. In accordance with the principle of confessional neutrality, no church or religious society has the right

121 Čeplíková, 2011, pp. 12-13.

122 Hrdina, 2004, p. 59, 67n.

123 Král, 2004, p. 72.

124 Madleňáková, 2010, p. 24.

125 This may be supported by art. 1 of the constitution, which says that the Slovak Republic is not bound to any ideology or religion. Čl. 1 ústavného zákona č. 460/1992 Zb., Ústava Slovenskej republiky.

126 The term 'thinking' implies every externally identifiable manifestation of a person that is motivated by his or her thinking, including conscience, religious belief, and faith. The term 'everyone' not only means every citizen of the Slovak Republic, but also every foreigner. Čikeš, 2008, p. 32.

127 Čl. 2, ods. 3 ústavného zákona č. 460/1992 Zb., Ústava Slovenskej republiky.

128 Čl. 24, ods. 4 and čl. 13, ods. 2 ústavného zákona č. 460/1992 Zb., Ústava Slovenskej republiky. See also Vozár, 2015. 
to dominative or privileged status. ${ }^{129}$ In accordance with the Bill of fundamental rights and freedoms, sect. 3 , art. 24 , of the constitution proclaims respect for and legally guarantees the individual identities of churches and religious societies that administer their own affairs, especially by establishing their own bodies, appointing clergy, teaching religion, setting up religious orders, and establishing other institutions, independent of state bodies. ${ }^{130}$ It is therefore clear that the constitution guarantees their autonomy and independence in internal matters, which relate to the organisation of church life and independence from state power. Sect. 4, art. 29 of the constitution also notes that religious organisations are separated from the state. ${ }^{131}$ Within this context it is necessary to clarify that these freedoms are only granted to the corporate entities, which may also solely object against their violations. ${ }^{132}$ This provision, in combination with sect. 1, art. 1 , is not a constitutional rule establishing the separation of church and state. ${ }^{133}$ Instead, it should be read as a plea to lawgivers and those who hold executive power to respect the principle of spiritual pluralism in law making. ${ }^{134}$ Although the state does not interfere with the internal matters of any church or religious society, the conditions in which those rights are exercised may by restricted by law to protect the public order, health, morality, and the rights and duties of others in a democratic society. ${ }^{135}$ The cited constitutional criteria for restricting the freedom of religious belief and faith, as well as the activities of churches and religious societies, are also the criteria used to register or deregister religious organisations. ${ }^{136}$

129 Robbers, 2000, p. 87. Thus the Slovak Republic does not identify itself with any church or religious society in the sense of a personal interconnection. Instead, it respects the legal equality of all churches and religious societies (§ 4, ods. 2 zákona č. 394/2000 Z.z.); citizens do not have to declare their religious affiliations to work in state or public services (§ 4, ods. 3 zákona č. 312/2001 Z.z. o štátnej službe; and § 2, ods. 1 zákona č. 308/1991 Zb. o slobode náboženskej viery a postavení cirkví a náboženských spoločností); it does not force any natural person to confess any religious belief (čl. 24 ústavného zákona č. 460/1992 Zb., Ústava Slovenskej republiky; and § 1, ods. 3 zákona č. 308/1991 Zb. o slobode náboženskej viery a postavení cirkví a náboženských spoločností); guarantees fundamental rights and freedom to everyone in its territory, regardless of his or her faith or religion (čl. 12, ods. 2 ústavného zákona č. 460/1992 Zb., Ústava Slovenskej republiky); does not allow the courts of the Slovak Republic to enforce the internal regulations of any church or religious society (Nález Ústavného súdu Slovenskej republiky sp. zn. III. US 64/00); does not allow its institutions to participate in creating or applying internal church or religious-society regulations. Orosz, 2009.

130 Madleňáková, 2010, p. 57.

131 Due to this, there is likewise no supervision over churches or religious societies. The Ministry of Culture of the Slovak Republic, through its Church Department, only implements rules associated with state religious laws; it also regularly distributes advisory funds to churches and religious societies from the state budget. Juran, 2008, p. 13.

132 Čeplíková, 2011, pp. 155-156.

133 Drgonec, 2004, p. 165.

134 Čeplíková, 2008, p. 20.

135 Čl. 24, ods. 4 ústavného zákona č. 460/1992 Zb., Ústava Slovenskej republiky.

136 Čič, 1997, p. 140n. 


\section{Guarantees provided by other sources of universally binding law}

The sources of state religious law, enacted in accordance with the Constitution of the Slovak Republic secundum et intra legem, are expressed in regulations of various kinds and legal force. First and foremost is the rather short Law No. 308/1991 Zb. on freedom of religious belief and the status of churches and religious societies. This law consists of 25 paragraphs and a supplementary list of churches and religious societies registered by the state. ${ }^{137}$ The content of this law can be divided into three parts, of which the first contains general provisions regulating religious freedom, its guarantees and realisation. Para. 1, sect. 1, which determines the fundamental rights, refers first and foremost to the Bill of rights and fundamental freedoms and indirectly to the state contractual obligations based on international human rights documents. It then transposes and specifies the provisions of art. 24 of the constitution by specifying that a confession of religious belief cannot be the basis for restricting a citizen's constitutionally guaranteed rights and freedoms, in particular the right to education, the choice or exercise of a profession, or access to information. ${ }^{138}$ This law refers to churches and religious societies as autonomous legal entities sui generis; the state approaches them individually and may cooperate with them, in accordance with the principle of partnership cooperation. ${ }^{139}$

137 As of 2021, the following churches and religious societies are registered in the Slovak Republic: 1. The Apostolic Church in Slovakia; 2. The Bahá'i Faith in the Slovak Republic; 3. Unity of the Brethren Baptists in Slovakia; 4. The Seventh-day Adventist Church, Slovak Congregation; 5. The Church of the Brethren in the Slovak Republic; 6. The Czechoslovak Hussite Church in Slovakia; 7. The Church of Jesus Christ of the Latter-day Saints; 8. The Evangelical Church of the Augsburg Confession in Slovakia; 9. The Evangelical Methodist Church, Slovak Province; 10. The Greek Catholic Church in the Slovak Republic; 11. The Christian Corps in Slovakia; 12. The New Apostolic Church in the Slovak Republic; 13. The Religious Society of Jehovah's Witnesses in the Slovak Republic; 14. The Orthodox Church in Slovakia; 15. The Reformed Christian Church in Slovakia; 16. The Roman Catholic Church in the Slovak Republic; 17. The Old-Catholic Church in Slovakia; and 18. The Central Union of Jewish Religious Communities in the Slovak Republic. Most of these churches and religious societies were recognised on the basis of so-called received registration. Príloha k zákonu č. 308/1991 Zb. o slobode náboženskej viery a postavení cirkví a náboženských spoločností and http://195.49.188.210/cirkev-a-nabozenske-spolocnosti/registrovane-cirkvi.

138 § 2 zákona č. 308/1991 Zb. o slobode náboženskej viery a postavení cirkví a náboženských spoločností.

139 They have their own internal structure, bodies, internal regulations, and ceremonies. They may associate with each other, establish communities, religious orders, societies, and other similar bodies. § 5, ods. 2 zákona č. 308/1991 Zb. o slobode náboženskej viery a postavení cirkví a náboženských spoločností. See also Juran, 2008, p. 13. Their individual character consists in their doctrinal and spiritual foundation. The state, however, recognises only registered churches and religious societies. § 4, ods. 4 zákona č. 308/1991 Zb. o slobode náboženskej viery a postavení cirkví a náboženských spoločností and zákon č. 192/1992 Zb. o registrácii cirkví a náboženských spoločností. However there are also approximately 50 unregistered non-traditional religious organisations in the Slovak Republic. Čeplíková, 2011, p. 122. 
Indirectly, they may be characterised as non-profit organisations in the non-governmental sector; along with saving souls, they carry out various public services and humanitarian activities. ${ }^{140}$ Although this law does not mention it, churches and religious societies have a similar status to public corporations. ${ }^{141}$ The second part of the law enumerates the rights of believers, as well as recognised churches and religious societies. The third part defines the conditions under which a church or religious society can become registered and claim appropriate financial subsidies from the state. ${ }^{142}$ The registering body is the Ministry of Culture of the Slovak Republic; during the process, a minimum of three people must represent each church or religious society. ${ }^{143}$ However, no provision in this law expressly discusses the use of religious symbols in the public sphere. ${ }^{144}$

As previously mentioned, the status of state religious law and members of the Catholic Church in Slovakia (both Roman and Greek Catholic) is also influenced by the Basic treaty between the Holy See and the Slovak Republic. Political representatives

140 Čikeš, 2010, p. 39.

141 As mentioned, the clergy of registered churches and religious societies enjoy the status of public officers, especially when conducting church marriages, which are equivalent to state-registry marriages in the Slovak Republic. § 5 zákona č. 36/2005 Z.z. o rodine.

142 The most important rights are as follows: the right to personal salaries for clergymen, financial contributions, partial funding for headquarters operations; the right to contend with the $2 \%$ income tax from natural persons and corporate entities; a tax exemption for church collections and gifts; an exemption from local real-estate taxes for sacral objects; an exemption from the Labour code; the right to teach religion at state schools; the right to establish church schools and special-purpose social and charitable institutions; the right to a church wedding and burial; the right to provide spiritual services to the army, the police, and at jails and social institutions; the right to access public-law media; the clergy's right to silence; the right to send their own representatives abroad and to receive representatives from foreign churches and religious societies, etc. As previously mentioned, members of non-registered churches and religious societies also have fundamental human rights and duties, according to the Constitution of the Slovak Republic. See also Macháčková and Dojčár, 2000, p. 11n.

$143 \S 18$ ods. 1 písm. i) zákona č. 575/2001 Z.z. o organizácii činnosti vlády a organizácii ústrednej štátnej správy; zákon č. 192/1992 Zb. o registrácii cirkví a náboženských spoločností and § 10, ods. 2 zákona č. 308/1991 Zb. o slobode náboženskej viery a postavení cirkví a náboženských spoločností. All churches and religious societies that want to achieve this status must prove that they have at least 50,000 adult members with a permanent address in the Slovak Republic. The Ministry of Culture of the Slovak Republic keeps the register of all church corporate entities, including those associated with registered churches and religious societies. Churches and religious societies that defy the law or registration conditions can be deregistered through an administrative procedure by the same body. § 19 zákona č. 308/1991 Zb. o slobode náboženskej viery a postavení cirkví a náboženských spoločností. Although the Ministry of Culture of the Slovak Republic is the central body of state administration in church and religious matters, it is not superior to them and may not interfere with their internal affairs or direct their activities. Čeplíková, 2011, p. 124.

144 Within this context, we refer again to the Bill of fundamental rights and freedoms in para. 1, sect. 1 , according to which everyone has the right to manifest his or her religious belief or faith alone or with others, privately or publicly, through worship, teaching, religious activities, or observing ceremonies. From this sentence, we may deduce that people also have the right to present themselves externally through the use of religious symbols. See also Wagnerová et al., 2012. 
in the late 1990s understood very well that such initiatives would have wide social support, given the high percentage of Catholic believers. ${ }^{145}$ Actual steps were taken in 1996; in 2000, after challenging negotiations involving financial and economic issues, the final text of this treaty was prepared for promulgation. The text was approved by the government and then discussed and approved by the National Council of the Slovak Republic. Finally, on 18 December 2000 in Vatican City the instruments of ratification were exchanged and the treaty came into force. ${ }^{146}$ It was followed by so-called partial treaties, initially included within the basic treaty, concerning financial provisions of the Catholic Church, education and the teaching of religion, and ministry in the armed forces. ${ }^{147}$ Neither the treaty on conscientious objection nor that on financial provisions were enacted; it seems unlikely that this will happen in near future. ${ }^{148}$ As these treaties are not self-enforceable, they may not be applied directly to relevant social relationships. However, the Slovak Republic is contractually obliged to ensure that its legislation fulfils these international-law obligations. Given the content of the basic treaty, the Slovak Republic has had to guarantee the inviolability of the sacred places and the seal of confession, respect specified church feasts as public holidays, provide facilities for the Catholic education of children in schools and pre-school institutions, and recognise marriages contracted under canon law. ${ }^{149}$ The use of religious symbols in the public sphere is an analogous issue, closely associated with state recognition of the right of the Catholic Church and its

145 According to the research 'Náboženstvo 1998', organised by the Sociological Institution of the Slovak Academy of Science, $68.7 \%$ of the citizens of the Slovak Republic were Catholics. Čeplíková, 2011, p. 192.

146 Čl. 24, ods. 2 Základnej zmluvy medzi Slovenskou republikou a Svätou stolicou. It was issued by the Foreign Ministry of the Slovak Republic on 23 August 2001, as no. 326/2001 Z.z. of the Laws of the Slovak Republic. This source is ranked with presidential international treaties that require the approval of parliament, as well as the government, and ratification by the President of the Slovak Republic. Šmid, 2001, pp. 39-41, 125.

147 These treaties are actual and concrete: Treaty no. 648/2002 Z.z. between the Slovak Republic and the Holy See on saving souls in the armed forces, issued by the Foreign Ministry of the Slovak Republic on 28 November 2002; Treaty no. 394/2004 Z.z. between the Slovak Republic and the Holy See on Catholic education and schooling, issued by the Foreign Ministry of the Slovak Republic on 9 July 2004. Following the former, the Military Ordinariate of Slovakia was established for the armed forces of the Slovak Republic, as a separate diocese for believers employed by the army, police, or prison service, with the bishop at its head. It has both canonical and state subjectivity and is organisationally integrated into the armed forces of the Slovak Republic. Moravčíková, 2007, p. 353. Both treaties were classified by the National Council of the Slovak Republic as international treaties, in accordance with art. 7, sect. 5 of the Constitution of the Slovak Republic, with priority to the laws of the Slovak Republic. Moravčíková, 2003, p. 117.

148 The financial treaty was replaced with a problematic new law on funding churches and religious societies. The main problem is the fact that it was issued unilaterally, not on the level of an international treaty. Zákon č. 370/2019 Z.z. o finančnej podpore cirkví a náboženských spoločností.

149 There is also a right to save souls in detention centers and houses of correction, where people are imprisoned as a punishment. Although all of rights of the Catholic Church were incorporated into other legal regulations in 1989, this treaty changed their legal force. Kubina, 2003, pp. 148-167. 
members to function freely and independently through public worship, preaching, and expressing the Catholic faith. ${ }^{150}$

The need to comply with the principle of parity complicated things for the Slovak Republic, because of presented worries of the minor churches and religious societies. In 1999, therefore, a draft law was submitted on the fundamental relationship between the state and churches and religious societies. The conclusion was reached that it would be sufficient to revise Law No. 308/1991 Zb. on freedom of religious belief and the status of churches and religious societies; this took place in 2000 . The revised law included a declaration of parity, clarifying the position of all churches and religious societies and recognising their right to conclude bilateral treaties with the state. According to several experts, this law settled all questions about the equality of churches and religious societies. ${ }^{151}$ Eleven religious bodies immediately took advantage of the revised law, submitting proposal for basic contract with state in 2001. This was approved in 2002, first by the government and then by the National Council of the Slovak Republic. ${ }^{152}$ Of course, since non-Catholic churches and religious societies are not subjects under international law, only contracting of internal treaty was topical. There are no similar sources in the legal system of Slovakia; this document is generally considered the atypical internal treaty sui generis. ${ }^{153}$ It is therefore unsurprising that the paradigms used to create this treaty and its content were drawn from the Basic treaty between the Holy See and the Slovak Republic. ${ }^{154}$ The main principle underpinning the regulation of mutual relationships was religious freedom: allowing believers to express their own convictions and attitudes. The Slovak Republic considers all contractual churches and religious societies to be independent, autonomous subjects. The treaty remains open to future registered churches and religious societies; new subjects may join with the unanimous consent of the subjects already engaged. ${ }^{155}$ Even this source has a normative character; from

150 Čl. 2, ods. 1 Základnej zmluvy medzi Slovenskou republikou a Svätou stolicou. See also Šmid, 2001, pp. 84-86.

$151 \S 4$, ods. 2 zákona č. 394/2000 Z.z. This provision must be interpreted within the context of art. 1 , sect. 1, the second sentence of the Constitution of the Slovak Republic, which declares that the Slovak Republic is not bound to any ideology or religion. In this way, the equality of churches and religious societies is expressed explicitly and settled legally, having previously been simply functional. See also Čeplíková, 2011, pp. 203-205.

152 We refer concretely to the following contractual subjects that represent, according to the 2011 census of population and housing, $10.4 \%$ of the citizens of Slovakia: Evangelical Church of the Augsburg Confession in Slovakia; the Reformed Christian Church in Slovakia; the Orthodox Church in Slovakia; the Evangelical Methodist Church, the Slovak Province; Unity of the Brethren Baptists in Slovakia; the Church of the Brethren in the Slovak Republic; the Seventh-day Adventist Church, the Slovak Congregation; the Apostolic Church in Slovakia; the Central Union of Jewish Religious Communities in the Slovak Republic; the Old-Catholic Church in Slovakia; and the Czechoslovak Hussite Church in Slovakia. See also Juran, 2008, p. 19.

153 Kanárik, 2002, pp. 84-85.

154 Čikeš, 2010, p. 71.

155 The complete text of the Agreement between the Slovak Republic and registered churches and religious societies (no. 250/2002 Z.z.) was included in the Collection of Laws of the Slovak Republic. 
the beginning, churches were expected to establish partial contracts in the same areas, as the Catholic Church did. ${ }^{156}$

Given the remaining sources of valid state religious law in the Slovak Republic, it is also important to analyse Law No. $245 / 2008 \mathrm{Zb}$. on education and schooling, the so-called Educational law. ${ }^{157}$ As previously mentioned, the problem of crosses in schools emerged for a short time during the First Czechoslovak Republic. Despite this, it is not covered by this legal source. Not even Law No. 279/1993 on educational institutions, which widened the domain of churches and religious societies, addresses this topic. ${ }^{158}$ Of course, Slovak lawmakers chose the same approach to the normative legal acts regulating the funding of churches and religious societies. Of particular note is Law No. 370/2019 Z.z. on the financial support of churches and religious societies; this law regulates financial subventions that fund the salaries of clergymen, contributions, and partially headquarters operations. ${ }^{159}$ The same is true for regulations that support the activities of churches and religious societies through taxes, customs, and other forms of relief. ${ }^{160}$ The objective problem is not reflected even by the provisions of Law No. 311/2001, the Labour code, which is valid until the end of 2021. Law No. 300/2005 Z.z., the Criminal code, contains several provisions that protect the freedom of thought, conscience and religion, including public practice. ${ }^{161}$ The same may be said of Law No. 301/2005 Z.z., the Criminal procedure

156 The field includes education, funding, pastoral care for the armed and police forces, and consciencious objection. Previously, there were other agreements, analogous to the Catholic Church agreement: the Agreement between the Slovak Republic and registered churches and religious societies on religious education and schooling (No. 395/2004 Z.z.); the Agreement between the Slovak Republic and registered churches and religious societies on pastoral care for members of the armed forces of the Slovak Republic (No. 270/2005 Z.z.). Interestingly, these agreements were approved by the government of the Slovak Republic and the National Council of the Slovak Republic and then signed by the President. This was not necessary, because they were not international treaties. However, the same approach was used to ensure equal treatment of all churches and religious societies in Slovakia. See also Čeplíková, 2011, p. 211. An expert in this field, who helped to draft the Basic treaty between the Slovak Republic and the Holy See, Prof. doc. JUDr. Marek Šmid, PhD., told me that more serious conflict over the use of religious symbols in the public sphere was avoided through these two contracts.

157 Of course, state religious law includes other regulations that have nothing to do with this problem and do not mention the use of religious symbols in the public sphere. They include Law No. 36/2005 Z.z. on family, which guarantees state recognition of a marriage contracted before the clergy of a registered church or religious society. \& 5 zákona č. 36/2005 Z.z. o rodine.

158 The same is true for Law No. 131/2002 Z.z. on universities.

159 Of the eighteen registered churches and religious societies do not claim a state subsidy Religious Society of Jehovah's Witnesses in the Slovak Republic, the Christian Corps in Slovakia, the Bahá'i Faith in the Slovak Republic, and the Church of Jesus Christ of the Latter-day Saints. Príloha č. 2 k zákonu 370/2019 Z.z.

160 Zákon č. 582/2004 Z.z. o miestnych daniach a miestnom poplatku za komunálne odpady a drobné stavebné odpady and zákon č. 595/2003 Z.z. o dani z príjmov.

161 § 340, ods. 3 (Neoznámenie trestného činu); 341, ods. 4 (Neprekazenie trestného činu); § 65, ods. 2, písm. b) (Trest vyhostenia); § 418 (Genocídium); § 423 (Hanobenie rasy, národa a presvedčenia); $\S 140$, písm e) (Osobitný motív); § 140a (Trestné činy extrémizmu); § 193 (Obmedzovanie slobody vyznania); § 359, ods. 1 (Násilie proti skupine obyvatelov a proti jednotlivcovi); § 189, ods. 2, písm. c) (Vydieranie); § 145, ods. 1, písm. d) (Vražda); and § 155, ods. 2, písm. c) (Ublíženie na zdraví). 
code. ${ }^{162}$ Neither legal source relates expressis verbis to the use of religious symbols in the public sphere. However, there is an indirect connection. The criminal offence of denigrating a race, nation, or belief can, under certain circumstances, involve religious symbols; an example would be destroying a statue, etc. ${ }^{163}$ Similarly, the criminal offence of restricting freedom of faith also protects manifestations of individual religious freedom. ${ }^{164}$ To conclude, Law No. 480/2002 Z.z. on asylum, which approves asylum for people who require it, also covers individuals persecuted for religious reasons. ${ }^{165}$

\section{The limits of religious expression through religious symbols}

As previously discussed, none of the relevant legal sources suggest limiting the use of religious symbols in Slovakia. In fact, this would be almost impossible, since almost all state symbols, including the national coat of arms, flag, and seal, include an early Gothic double cross that stands on the second of three hills, a typical Christian image. ${ }^{166}$ Naturally, this symbol appears in public areas everywhere. ${ }^{167}$ According to the law on state symbols in the Slovak Republic, they must be used by the supreme legislative authority (the National Council of the Slovak Republic), executive bodies (the government, president, and ministries), the offices of public prosecutors, the armed forces, state schools and educational institutions, territorial administrative offices, state scientific organisations, museums, galleries, and sportspeople who

$162 \S 130$, ods. 2 (Právo svedka odopriet výpoved'); § 510, ods. 2, písm. b) (Povolenie vydania); and § 4 (Spolupráca so záujmovými združeniami občanov a s dôveryhodnou osobou). Distinctively, the right to refuse to testify is protected, as is the right of churches and religious societies to participle in penitentiary work with convicted persons. § 17, ods. 4 zákona č. 171/1993 Zb. o Policajnom zbore SR; § 8 vyhlášky č. 346/2008 Z.z. (Poriadok výkonu trestu); and § 44, ods. 1 zákona č. 221/2006 Z.z. o výkone väzby. The right of convicted persons to the cure of their souls is also expressed in other legal sources. § 68, ods. 1 zákona č. 475/2005 Z.z. o výkone trestu odňatia slobody. Provisions include concrete provisions associated with articles of the Basic treaty between the Slovak Republic and the Holy See and the Agreement between the Slovak Republic and registered churches and religious societies. Čeplíková, 2008, p. 23. See also Nemec, 2013, p. 233-240.

$163 \S 423$ zákona č. 300/2005 Z.z., Trestný zákon.

164 § 193 zákona č. 300/2005 Z.z. See also Čentéš, 2018, pp. 390-391, 933-936.

165 Under the term 'religion' this law includes the expression of opinions and types of personal and social behaviour based on religious belief, which can also include the use of religious symbols in the public sphere (for example, a conviction for holding the Bible in Saudi Arabia). § 8, písm. a) zákona č. 480/2002 Z.z. o azyle.

$166 \S \S 2$, ods. 1; 6a and 13b zákona č. 18/1993 Z.z. o štátnych symboloch Slovenskej republiky a ich používaní. See also Halász, 2020, p. 72n; Vrtel, 2010.

167 Of course, that is also the reason why this symbol is protected by criminal law. § 364, ods. 1, písm. b) zákona č. 300/2005 Z.z., Trestný zákon. See also Mašlanyová, D. Postih extrémizmu podla slovenského Trestného zákona. In Záhora, 2012, pp. 148-150. 
represent Slovakia. These symbols appear in interiors, but also, of course, on buildings. ${ }^{168}$ For example, the state symbol must be printed on the school reports produced by private and church schools, which are not required to use any other symbols for this purpose. ${ }^{169}$ Of course, the main reason for this regulation is the knowledge, among lawgivers, that schools (and particularly church schools) would rather use their own religious symbols than state symbols. At the same time, state institutions can only use state symbols; the use of religious ones is out of the question, even if organisation heads would like to do so. To date, there has never been a case in Slovakia on this issue. In state schools, universities, and hospitals, when minor disputes arise, they are usually resolved promptly by the institution. ${ }^{170}$

After the European Court for Human Rights prohibited the exhibition of crosses in schools (Lautsi and others vs Italy: complaint No. 30814/06), the National Council of the Slovak Republic responded with the 2009 Declaration on Installing Religious Symbols in Schools, ${ }^{171}$ which declared that the European court's decision undermined the cultural heritage and Christian history of Europe. As it was a tradition in several European states to display crosses in schools and public institutions and spaces, respecting this tradition could not be seen as limiting the freedom of religious belief or violating the rights of parents to raise their children in accordance with their own convictions. ${ }^{172}$ For this reason, the National Council of the Slovak Republic argued that every member state of the European Union had the right to install religious symbols in schools and public institutions. ${ }^{173}$ The Ministry of Culture of the Slovak Republic, which represents the central state administration responsible for churches and religious societies, is aware of a few such cases and must intervene

$168 \S 4$ zákona č. 18/1993 Z.z. o štátnych symboloch Slovenskej republiky a ich používaní.

$169 \S \S 3$, ods. 5 and 5, ods. 1 zákona č. 18/1993 Z.z. o štátnych symboloch Slovenskej republiky a ich používaní and § 3, písm. q) zákona č. 245/2008 Z.z. o výchove a vzdelávaní, Školský zákon.

170 Hospital chapels are commonly established in hospitals (with management approval) and pastoral centres in universities (as agreed between the relevant church or religious society and the university). Čl. 16 Základnej zmluvy medzi Slovenskou republikou a Svätou stolicou vyhlásenej pod číslom 326/2001 Z.z. ako oznámenie Ministerstva zahraničných vecí and čl. 16 Dohody medzi Slovenskou republikou a registrovanými cirkvami a náboženskými spoločnostami publikovanej pod č. 250/2002 Z.z.

171 In addition, research carried out by the Focus agency found that two-thirds of respondents opposed a law forbidding the use of religious symbols at schools in Slovakia. See: https://bit.ly/2XXfKeZ. See also Čurila, 2010.

172 Within this context, one can mention the example of a strong, faithful teacher who hung a cross in the classroom of a state school; following complaints from parents, it had to be removed, under the direction of the schoolmaster. In 2006, in the town of Svit, a nun began working in the town nursery school. Her habit had the sign of the cross. Some parents objected that their children were being exposed to the influence of the Catholic faith, which violated their right to raise their children in accordance with their own convictions. At the same time, in an elementary school in Budkovce, almost all rooms are decorated with crosses and no one complains because the place has a strong Christian tradition. See: https://bit.ly/3ARFms5.

173 Vyhlásenie Národnej rady Slovenskej republiky o umiestňovaní náboženských symbolov v školách a vo verejných inštitúciách v súlade s kultúrnou tradíciou krajiny, schválené Národnou radou Slovenskej republiky uznesením z 10. decembra 2009, číslo 1845. Available at: https://bit.ly/3F20U7N. 
sporadically. ${ }^{174}$ In some cases, registration has been denied due to religious intolerance, directed against the religious symbols of other churches and religious societies. In particular, the Christian associations in Slovakia have applied to register three times and been rejected each time; this case is now being tried by the Supreme Court of the Slovak Republic. The reason for this rejection was religious intolerance, as the Christian associations were accused of abusing (even destroying) religious symbols belonging to the Catholic Church. Expert testimony has shown that members of this religious society were encouraged to commit these misdeeds by their own pastors.

Performers have occasionally abused religious symbols in Slovakia. In 2014, for example, various religious symbols (a cross, a rosary, religious statues, and pictures of the Pope, Vatican, and cardinals) were damaged or destroyed in a rap video. ${ }^{175}$ Criminal justice officials requested a report for the Ministry of Culture of the Slovak Republic and its employees asserted (although it was not in their competency to decide) that art. 5, sect. 2 of the Basic treaty between the Holy See and the Slovak Republic guarantees the inviolability of sacred places abused through such behaviour. ${ }^{176}$ In addition, members of various extremist movements have violated criminal law by using, profaning, or destroying religious symbols ${ }^{177}$ For this reason, competent bodies generally specify the procedures for controlling extremists through executive enactments, which are instructions directly related to criminal justice. ${ }^{178}$ The misuse of religious iconographies, including symbols (especially, the so-called iron cross, Celtic cross, and spinning-wheel symbol) is a typical feature of rightist extremist attitudes, usually in reference to paganism or individual perceptions of Christianity. ${ }^{179}$ Various neo-Nazi movements use the religious symbols of Nordic mythology (especially the god Odin), as well as Christian symbols. ${ }^{180}$ As in other countries, religious symbols in Slovakia are misused or destroyed by certain sects, such as Satanists.

The Council for the advertising regularly addresses the problem of religious symbols in the public sphere, using its own code to consider advertising-related issues. In 1997, it responded to a complaint made by Catholics that a poster promoting the movie 'The People vs. Larry Flynt' profaned the cross as a Christian religious symbol. The Council rejected that complaint on grounds that the poster did not rudely or undoubtedly offend religious consumers; however, it also advised the sponsor of the advertisement to consider the placement of the posters carefully and sensitively. ${ }^{181}$

174 This useful information was provided by an employee of this ministry, PhDr. Radovan Čikeš, PhD., to whom I am very grateful.

175 See: https://bit.ly/3EX1GmH.

176 MK-946/2014-260/8990.

177 § 130, ods. 7, písm. a) zákona č. 300/2005 Z.z., Trestný zákon.

178 Nariadenie Ministerstva vnútra SR č. 45/2004 o postupe v oblasti boja s extrémizmom a o zriadení monitorovacieho strediska rasizmu a xenofóbie.

179 See also Milo, 2005, pp. 28, 30 and Hetteš, 2015, p. 57.

180 See also Chmelík, 2000.

181 See: https://bit.ly/3marL9n. 
In 2011, the Council responded to another complaint that an advertisement for men's body spray misused the religious symbol of angels to provoke sexual desire. The Council similarly rejected this complaint as baseless, arguing that angels were not exclusively perceived as purely religious symbols. ${ }^{182}$ Another complaint argued that a Facebook poster, for an event called Helloqueen 2019, misused the religious and national symbols of the Lady of Sorrows (Mater Dolorosa) and her Son Jesus Christ by imitating a Pieta. This motion too was denied as baseless on grounds that the '... advertisement did not emanate and had no concern to display religious symbols in relation to the religion or certain group of citizens'. ${ }^{183}$ The Council for broadcasting and retransmission sometimes deals with analogous complaints. For example, in 2013, it refused to uphold the complaint of three subjects who felt that certain gloss to the election of a new pope treated religion in a profane or vituperative way. ${ }^{184}$ Among other Slovak regulations, pictograms representing churches and synagogues are used on traffic signs. ${ }^{185}$ Similarly, trademarks that contain high-value or religious symbols can not be registered in the Slovak Republic. ${ }^{186}$

\section{The system of legal protection}

As noted above, no legal cases have directly or indirectly raised the issue of the use of religious symbols in the public sphere in Slovakia. To date, all minor and more significant issues have been settled out of court, unusually by agreement and to the full satisfaction of all involved. Slovak courts are by no means burdened with religious cases, although such cases do appear occasionally. Most of the time, these cases involve the restitution of church property, which has not been returned to the church or religious society within the legally required timeframe. There have also been a few labour-law cases involving clergy, ex-clergy, and the registered churches and religious societies that employ them. Slovak courts (including the Supreme Court of the Slovak Republic) did not deal with the processes to deregister churches or religious societies. ${ }^{187}$ They even did not decide cases related to the activities of non-registered

182 See: https://bit.ly/2Y8MKBl.

183 https://refresher.sk/78487-Katolici-nahlasili-reklamu-propagujucu-DJku-BComplex-vraj-haninarodny-symbol.

184 Správa o stave vysielania v Slovenskej republike a o činnosti Rady pre vysielanie a retransmisiu za rok 2013, p. 72.

185 https://www.ssc.sk/sk/technicke-predpisy-rezortu/zoznam-kulturnych-cielov-a-atraktivitcestovneho-ruchu/piktogramy-legenda.ssc.

186 § 5, ods. 1, písm. j) zákona č. 506/2009 Z.z. o ochranných známkach. In one example, an application to register Ave maria for packaging beer, soft drinks, fruit juices, and alcoholic beverages and wine was rejected. Hajnalová, 2010, p. 29.

187 Čl. 18 zákona č. 125/2016. 
churches or religious societies. ${ }^{188}$ The Constitutional Court of the Slovak Republic has established one of the most important and widely known court practices by ruling that church and religious society rules are not sources of law of the Slovak Republic; every citizen has a right to an independent and impartial state trial, even when a case was previously decided by a church court. ${ }^{189}$ In another finding, the same court confirmed that requiring numerous members to register a church or religious society is not unconstitutional, since it is necessary to differentiate between the right to manifest a religion or faith and right to register a church or religious society. ${ }^{190}$ The court also decided that the right to refuse military service for reasons of conscience or religious belief may be conditioned by the need for every group of entitled persons to keep the appointed time. It is therefore impossible to refuse military service because of a recent change of religious belief or faith. ${ }^{191} \mathrm{~A}$ local court decided a case in which a member of the Greek Catholic Church applied to the state court to force the church to erase the baptismal mark caused by being baptised as a child. The court denied this request, declaring that the state could not interfere with the doctrine of an individual church or religious society. ${ }^{192}$

\section{Conclusions}

As the Introduction notes, freedom of thought, conscience, and religion are fundamental human rights that guarantee freedom and dignity in the spiritual and intellectual sphere; some experts even consider them more important than the right to life. ${ }^{193}$ This conception of the structure of human dignity is based on individual rights; it draws on European cultural traditions with Judeo-Christian roots. ${ }^{194}$ The European states essentially accept that human rights are not merely expressed in the

188 Juran, 2008, p. 14. For example, there were efforts to register a so-called Atheist Church of Unbelievers with the Ministry of Culture of the Slovak Republic. The Church Department refused to register the group on 18 December 2006 and the case was appealed to the Supreme Court, which dismissed the suit on 23 August 2007. Rozhodnutie č. MK 4457/2006-320/22106. In Slovakia, more than ten churches, religious societies, and prank fellowships made similar attempts; even another group that called themselves the shepherd's pipers ('fujaristi'). See: https://bit.ly/3kLhBw7 and https://bit.ly/3kLZ9U8.

189 Nález Ústavného súdu Slovenskej republiky sp. zn. III. US 64/00.

190 Nález Ústavného súdu Slovenskej republiky sp. zn. 10/08.

191 Nález Ústavného súdu Slovenskej republiky sp. zn. PL ÚS 18/95. Compulsory military service, replaced in some cases with civilian service, ended on 31 December 2005, in connection with the professionalisation of the Slovak army. Zákon č. 346/2005 Z.z. o štátnej službe profesionálnych vojakov ozbrojených síl Slovenskej republiky.

192 Nález Ústavného súdu Slovenskej republiky sp. zn. III. ÚS 313/09. See also Bubelová, 2010, pp. 257-262.

193 Pavlíček, 2004, p. 113.

194 Čikeš, 2008, p. 30. 
constitution or laws of a given state, but also in principles and values that go beyond the state, constitution, and the law itself. These criteria for human and civil rights are generally recognised in the democratic world. ${ }^{195}$ They also underpin the definition of freedom of thought, conscience, religious belief, and faith in the Constitution of the Slovak Republic. ${ }^{196}$ In contrast to that of the Czech Republic, the Slovak constitution expressly guarantees the right to manifest individual thinking. This right has been interpreted by the Constitutional Court of the Slovak Republic as including every externally identifiable expression of an individual, motivated by his or her thoughts, conscience, religious beliefs, or faith. ${ }^{197}$ For this reason, Slovakian law protects all manifestations of religion or thinking at the same level, within uniform legal limits. ${ }^{198}$ The main principle in this constitutional article is the axiom that everyone has the right to manifest and/or confess his or her convictions, which can only be limited to protect public security and the rights of others. The European Court for Human Rights reasoned in a similar way when protecting art. 9 of the European Convention on Human Rights. ${ }^{199}$ Freedom of religion is thus considered a universal, fundamental right of every person and a criterion that determines the application of democratic principles in practice. ${ }^{200}$

Law No. 308/1991, on freedom of religious belief and the status of churches and religious societies, defines them as voluntary associations with religious beliefs within organisations established to enable membership in those religious beliefs, through the internal regulations of given churches or religious societies. ${ }^{201}$ From a political point of view, they can be defined as individual institutions sui generis, which cannot be classified as other types of organisations. ${ }^{202}$ Their specific nature reflects a doctrinal and spiritual foundation, without which no church or religious society can be registered and recognised by the state. ${ }^{203}$ Although the Ministry of Culture of the Slovak Republic administers this sector, this is not a form of controlin fact, it is just the opposite. It supports efforts to develop perfect cooperation by providing proper conditions for religious activities that qualify as socially useful. In the Slovak Republic, the need to establish a regime of high-class cooperation is related, not only to the fact that a high proportion of the public is religious, but also to the extensive involvement of churches and religious societies in social, educational,

195 Blahož, 2005, p. 15.

196 Čikeš, 2008, p. 32.

197 Uznesenie Ústavného súdu Slovenskej republiky sp. zn. Pl. ÚS 18/95.

198 Čl. 24, ods. 4 ústavného zákona č. 460/1992 Zb., Ústava Slovenskej republiky. See also Madleňáková, 2010 , p. 57.

199 If this article is violated, the given state cannot use national security as a reason for restricting these rights. Guiora, 2009.

200 Šabo, 2008, p. 33.

201 § 4, ods. 1 zákona č. 308/1991 Zb. o slobode náboženskej viery a postavení cirkví a náboženských spoločností.

202 Čeplíková, 2011, p. $122^{289}$.

203 §§ 10-13 zákona č. 308/1991 Zb. o slobode náboženskej viery a postavení cirkví a náboženských spoločností. 
and charitable areas. The relevant question of religiousness in Slovakia is extremely interesting, providing educational content for several socioscientific fields. In most prior studies, respondents have commented on the ethical aspects of religion and its ability to stabilise the family and interpersonal relationships. Most believers also find in religion meaning and purpose of life, while those with less faith highlight its ability to help individuals deal with difficult life situations. ${ }^{204}$

As previously noted, the country suffered decades of lost freedom under the communists, who limited both institutional and individual religious freedom. After the fall of communism, the state tried hard to establish and guarantee future religious freedom, thus enabling the development of religious and church life. This approach naturally promoted excellent collaboration between the state and churches and religious societies, benefitting all concerned. It is reflected in the accommodating stance of state religious law, which has enabled the development of religious freedom on a large scale. ${ }^{205}$ These relationships were strengthened, particularly with the Catholic Church, when the Basic treaty between the Holy See and the Slovak Republic was enacted in 2001, with other churches and religious groups following suit in 2002, through the Agreement between the Slovak Republic and registered churches and religious societies. Domestic and foreign experts and the public approved of the fact that this document managed to unite eleven ideologically different religious subjects; it is often cited as an example worth following. ${ }^{206}$ For the most part, the various churches and religious societies also have excellent relationships, as evidenced by the 2001 agreement between the Catholic Church and the Evangelical Church of the Augsburg Confession to mutually recognise baptism. The success of Slovak state religious law in meeting social needs can also be deduced from the lack of serious issues arising over the use of religious symbols. As noted above, Christian symbols are an integral part of Slovak national identity; in particular, the national symbol of the double cross is typical and natural for Slovakia, just as the Star of David is for Israel. Although cases appear sporadically, they have never been brought before the court, since the parties concerned have always managed to agree on a solution.

It is clear that for good mutual relationships between the state and churches and religious societies was necessary to compensate them for the loss of church property during the communist regime. In fact, the Slovak Republic was the first post-communist country to implement a law of restitution, requiring the return of real estate and movable estates to churches and religious organisations. ${ }^{207}$ Such restitutions did not lead to their complete economic emancipation, although several governments

204 On the other hand, most were critical of the involvement of churches and religious societies in politics. See also Čikeš, 2010, pp. 88 and 90.

205 Given this account, it makes sense to compare the legal regulation of the relationship between the state and churches and religious societies in the Slovak Republic with the Czech Republic, within the European context. As a natural consequence of their common historical development after 1918, both countries followed the practice of Austria-Hungary. Juran, 2008, p. 12.

206 Čikeš, 2002, p. 183.

207 Čeplíková, 2011, p. 161. 
considered this eventuality from 1992 onwards. In 1996, for example, the following models were proposed: retaining a system of financing based on the state budget; a system of taxation resembling that in Italy and Spain (preferred by the Catholic Church); financing churches and religious societies through individual contributions (favoured by the Evangelical Church of the Augsburg Confession); or making financial contributions to churches and religious societies in form of tax deduction (preferred by smaller evangelical churches and religious societies). ${ }^{208}$ We suggest eventually, de lege ferenda, that a system of tax assignment, in which every taxpayer can decide where to allocate some of his/her taxes should be preferred. Under this system, taxpayers could choose churches, religious societies, or other publicly useful recipients or aims. ${ }^{209}$ The Slovak legal system already provides taxpayers with the opportunity to allocate $2 \%$ of their assessed income tax to the corporate entity of their choice, including entities run by churches or religious societies. ${ }^{210}$ Despite some criticism of the current model of financing, the new Law No. 370/2019 Z.z. on the financial support of churches and religious societies, strives to sustain it, primarily because this model appears to function very well in practice. ${ }^{211}$ Looking back over the historical development of Slovakia, it is also possible to speak metaphorically about the traditional Congrua system continuing. ${ }^{212}$

In Slovakia, the main topic of discussion has been the treaty on conscientious objection, anticipated following the Basic treaty between the Slovak Republic and the Holy See, as well as the Agreement between the Slovak Republic and registered churches and religious societies. This absolute right allows the individual to refuse to undertake civil, work-related, official, or other duties that conflict with his or her conscience or religious belief. As previously discussed, the last effort to implement this treaty led to the fall of the government. The objections were that it interfered with state sovereignty and civil principles, violating the principles of equality and non-discrimination. ${ }^{213}$ Opponents also argued that the right to conscientious objection could not be applied to everyone without exception, as it was unclear how people who did not belong to any church or religious society would apply it. ${ }^{214}$ Contemporary changes in society suggest that these objections will be raised again. Slovakia thus even nowadays faces politically and ideologically motivated discussions that ignite useless passions, even though most of the proposed rights are

208 Juran, 2008, p. 17.

209 Under these circumstances, the tax rate would have to be $4 \%$ - several times more than in states that apply this model. In Spain, for example, the assignment represents $0.5 \%$, in Italy $0.8 \%$, and in Hungary $1 \%$ of the total tax. Although it would be appropriate to add funds from the state budget, this procedure casts doubt on the propriety of the solution in general. See also Čikeš, 2010, p. 58.

210 § 50, ods. 4 zákona č. 595/2003 Z.z., Zákon o dani z príjmov.

211 Nemec, 2019, pp. 131-149.

212 Tretera, 2002, p. 53.

213 Several experts remarked that Slovakia would be the first state in the world to give believers such an extensive opportunity to follow the doctrinal principles of their own churches or religious societies in common, as well as in professional life. Čeplíková, 2011, p. 216.

214 Poláček, 2007, pp. 186-187. 
already protected by the legal system. ${ }^{215}$ From the perspective of de lege ferenda, the state may rethink the conditions of registration for churches and religious societies, considered to be the most severe in the entire European Union. Already, the high membership bar has been raised to 50,000, making it impossible for smaller religious organisations to obtain the status of official churches or religious societies recognised by the state. After all, even concerns that bar set at 20,000 members would make it necessary to register various non-established religious organisations were never probated..$^{216}$

215 In this context, the three most serious activities related to life and death are the termination of pregnancy, sterilisation, and assisted human reproduction; all are expressis verbis contained in Law No. 576/2004 on healthcare. This legal source allows medical employees to refuse to carry out these medical interventions, based on their own beliefs. § 12, ods. 2, písm. c) zákona č. 576/2004 Z.z. o zdravotnej starostlivosti. A related document is the ethical code for medical employees, which states that medical employees cannot be asked to carry out procedures that they believe to be wrong, unless there is an immediate threat to a person's life or health. If the medical employee wishes to conscientiously object, he or she must inform his or her employer and patients. § 2, ods. 3 Etického kódexu zdravotníckeho pracovníka, príloha k zákonu č. 578/2004 Z.z. o poskytovateloch zdravotnej starostlivosti, zdravotníckych pracovníkoch, stavovských organizáciách v zdravotníctve a o zmene a doplnení niektorých zákonov.

216 For this reason, some authors suggest two-step registration. First, the church or religious society would obtain the legal personality of a civil-society organisation; then, after a period of time specified by law, it would also acquire the status of a registered church or religious society. Čikeš, 2010, p. 47. 


\section{Bibliography}

BALÁž, P. (2000) 'Trestné právo a jeho úlohy pri ochrane l’udských práv a slobôd v našej spoločnosti'. In Barancová, H., Krsková, A. (eds.) Ludské práva na prahu tretieho tisícročia. Trnava: Právnická fakulta Trnavskej University.

BALÍK, S., HANUŠ, J. (2007) Katolická církev v Československu 1945-1989. Brno: Centrum pro studium demokracie a kultury.

BARÁnY, E. (2007) Pojmy dobrého práva. Žilina: Poradca podnikatel’a.

BLAHOŽ, J. (2005) Sjednocující se Evropa a lidská a občanská práva. Praha: ASPI.

BUBELOVÁ, K. (2010) 'Slovenský civilní soud rozhodoval o neplatnosti křtu'. In Moravčíková, M., Valová, E. (eds.) Ročenka Ústavu pre vzṫahy štátu a cirkví 2009. Bratislava: Ústav pre vztahy štátu a cirkví.

BUŠEK, V. (1931) 'Pomer štátu k církvím v ČSR'. In Dědina, V. (ed.) Československá vlastivěda. Díl V. Praha: Sfinx.

CAmpenhausen, A. (1994) 'Der heutige Verfassungsstaat und die Religion'. In Listl, J., Pirson, D. (eds.) Handbuch des Staatskirchenrechts der Bundesrepublik Deutschland. Erster Band. Berlin: Duncker \& Humblot.

CAMPEnHAusen, A. (2002) Lexikon für Kirchen- und Staatskirchenrecht. Band 2. G-M. Paderborn: Ferdinand Schoningh.

CASAROLI, A. (2001) Trýzeň trpělivosti. Svatý stolec a komunistické země (1963-1989). Kostelní Vydří: Karmelitánské nakladatelství.

ČEnTÉŠ, J. A KOL. (2018) Trestný zákon. Vel'ký komentár. 4. aktualizované vydanie. Žilina: Eurokódex.

ČEPLÍKOVÁ, M. (2008) 'Súčasný stav konfesného práva v Slovenskej republike'. In Grešková, L. (ed.) Vztahy štátu a cirkví v Európe: Súčasné otázky a trendy na začiatku 21. storočia. Zborník z rovnomennej medzinárodnej konferencie, ktorú usporiadal Ústav pre vztahy štátu a cirkví $v$ Bratislave $v$ dňoch 8-10. novembra 2007. Bratislava: Ústav pre vztahy štátu a cirkví, Bratislava.

ČEPLÍKOVÁ, M. (2011) Konfesné právo v Slovenskej republike. Vybrané kapitoly z histórie a súčasnost'. Bratislava: Ústav pre vztahy štátu a cirkví.

CHENAUX, P. (2012) Katolická církev a komunismus v Evropě (1917-1989). Od Lenina k Janu Pavlu II. Praha: Rybka Publishers.

CHMELÍK, J. (2007) Symbolika extrémistických hnutí. Brno: Armex.

ČIČ, M. A KOL. (1997) Komentár k Ústave Slovenskej republiky. Martin: Matica slovenská.

ČIKEŠ, R. (2002) 'Zmluva medzi Slovenskou republikou a registrovanými cirkvami a náboženskými spoločnostami'. In Kolektív autorov: Ročenka Ústavu pre vztahy štátu a cirkví 2001. Bratislava: Ustav pre vztahy štatu a cirkvi.

ČıKEŠ, R. (2008) 'Náboženská sloboda v slovenskom konfesnom systéme’. In Grešková, L. (ed.) Vztahy štátu a cirkví v Európe: Súčasné otázky a trendy na začiatku 21. storočia. Zborník z rovnomennej medzinárodnej konferencie, ktorú usporiadal Ústav pre vztahy štátu a cirkví $v$ Bratislave $v$ dňoch 8-10. novembra 2007. Bratislava: Ústav pre vztahy štátu a cirkví, Bratislava.

ČIKEŠ, R. (2010) Vzt̉ahy štátu a cirkví na Slovensku. Bratislava: Ústav pre vztahy štátu a cirkví. ČURILA, D. (2010) 'Sloboda náboženského vyznania a formálna spravodlivost' vo veci Lautsi v. Taliansko'. In Dávid, R., Sehnálek, D., Valdhans, J. (eds.) Dny práva 2010. Brno: Masarykova univerzita. 
DAVALA, M. (2013) 'Vývoj v úprave rovnosti ako základnej hodnoty'. In Kolektív autorov: Vybrané texty $k$ l'udským právam. Bratislava: Univerzita Komenského v Bratislave.

DEJMEK, J. (2004) 'Vztahy mezi ČSR a Vatikánem v meziválečnému období'. In Loužek, M. (ed.) Vztah církví a státu. Praha: Centrum pro ekonomiku a politiku.

DoE, N. (2011) Law and Religion in Europe. A Comparative Introduction. Oxford: Oxford University Press.

DOLINSKÝ, J. (1999) Cirkev a štát na Slovensku v rokoch 1918-1945. Trnava: Dobrá kniha.

DRGONEC, J. (2004) Ústava Slovenskej republiky. Komentár. Šamorín: Heuréka.

DUfFAR, J. (1995) 'Le regime constitutionnel des cultes'. In European Consortium for Churchstate Research. Paris, Milan: Litec - Giuffrè.

EVANS, C. (2003) Freedom of Religion under the European Convention on Human Rights. Oxford: Oxford University Press.

EvANS, C. (2012) 'Religion and Freedom of Expression'. In Witte, J., Jr., Green, M. Ch. (eds.) Religion and Human Rights. Introduction. Oxford: Oxford University Press.

FERRARI, S. (1995) 'Church and State in Europe. Common Pattern and Challenges'. In European Journal for Church and State Research. Vol. 2.

FIALA, P., HANUŠ, J. (2001) Katolická církev a totalitarismus v českých zemích. Brno: Centrum pro studium demokracie a kultury.

GAREK, M. (2010) ‘Školstvo na území hornej Oravy v rokoch 1939-1945'. In Sokolović, P. (ed.) Život $v$ Slovenskej republike. Slovenská republika 1939-1945 očami mladých historikov IX. Bratislava: Ústav pamäti národa.

GREŠKOVÁ, L. (ed.) (2008) Vzt̉ahy štátu a cirkví v Európe: Súčasné otázky a trendy na začiatku 21. storočia. Zborník z rovnomennej medzinárodnej konferencie, ktorú usporiadal Ústav pre vzṫahy štátu a cirkví v Bratislave $v$ dňoch 8-10. novembra 2007. Bratislava: Ústav pre vztahy štátu a cirkví, Bratislava.

GuiorA, A. N. (2009) Freedom from Religion. Rights and National Security. Oxford: Oxford University Press.

HAJNALOVÁ, Z. (2010) 'Ochranné známky (druhy označení a zákon o ochranných známkach)'. In Hajnalová, Z. (ed.) Zborník z konferencie Duševné vlastníctvo na Slovensku X (pri príležitosti Svetového dňa duševného vlastníctva). Banská Bystrica: Úrad priemyselného vlastníctva Slovenskej republiky.

HALÁsZ, I. (2020) Minulost' a symbolika v ústavách štátov strednej Európy. Praha: Ústav státu a práva AV ČR.

HALAS, F. X. (2002) Vztahy mezi státem a církví hlediska jejich mezinárodního rozměru. Olomouc: Univerzita Palackého v Olomouci, Cyrilometodějská teologická fakulta.

HANuš, J. (ed.) (2002) Křestanství a lidská práva. Brno - Praha: Centrum pro studium demokracie a kultury - Vyšehrad.

HetÉNYi, M., IVANiČ, P. (2010) 'Poznámky k šíreniu kultu sv. Cyrila a Metoda v rokoch 19391945 na príklade mesta Nitra'. In Sokolović, P. (ed.) Život v Slovenskej republike. Slovenská republika 1939-1945 očami mladých historikov IX. Bratislava: Ústav pamäti národa.

HETTEŠ, M. (2015) Ludské práva a sociálna ochrana v sociálnej práci. Bratislava: Vysoká škola zdravotníctva a sociálnej práce sv. Alžbety.

HLAvovÁ, V. (2008) 'Cirkev a povojnová pozemková reforma 1945-1948'. In Dobrotková, M., Kohútová, M. (eds.) Slovensko a Svätá stolica. Trnava: Slovenský historický ústav v Ríme - Trnavská univerzita v Trnave.

HoRÁk, Z. (2011) Církve a školství. Praha: Grada. 
HraboveC, E. (2008) 'Slovensko a Svätá stolica 1918-1939 v kontexte medzinárodných vztłahov'. In Dobrotková, M., Kohútová, M. (eds.) Slovensko a Svätá stolica. Trnava: Slovenský historický ústav v Ríme - Trnavská univerzita v Trnave.

HRDINA, A. (2004) Náboženská svoboda v právu České republiky. Praha: Eurolex Bohemia.

JÄGER, P., MOLEK, P. Svoboda projevu. Demokracie, rovnost a svoboda slova. Praha: Auditorium. JURAN, J. (2008) 'Vztah cirkví a štátu'. In Grešková, L. (ed.) Vzṫahy štátu a cirkví v Európe: Súčasné otázky a trendy na začiatku 21. storočia. Zborník z rovnomennej medzinárodnej konferencie, ktorú usporiadal Ústav pre vztahy štátu a cirkví v Bratislave $v$ dňoch 8-10. novembra 2007. Bratislava: Ústav pre vztahy štátu a cirkví, Bratislava.

KAISER, W., VARsori, A. (2010) European Union History: Themes and Debates. London: Palgrave Macmillan.

KALNÝ, M. (1995) Církevní majetek a restituce. Praha: Občanský institut.

KAMENEC, I. (2011) 'The Slovak State, 1939-1945'. In Teich, M., Kováč, D., Brown, M. D. (eds.) Slovakia in History. Cambridge: Cambridge University Press.

KANÁRIK, I. (2002) Informatívne pôsobenie práva. Zborník z medzinárodnej konferencie: Public administration \& informatics within public administration 2002, Lázně Bohdaneč 16.-18. 9. 2002. Pardubice: Univerzita Pardubice, Fakulta ekonomicko-správní.

KIDERLEN, H. J. (1993) Die Einingung Europas und die Staat-Kirche-Ordnung. Münster: Marré.

KINDL, V. (1998) 'Kirchen, Religionsgemeinschaften und Bekenntnisfreiheit in der Rechtsordnung der Tschechischen Republic nach 1945'. In Mohnhaupt, H., Schonfeldt, H.-A. (eds.) Normdurchsetzung in Ostereuropäsichen Nachkriegsgesellschaften (1944-1989) Einfuhrung in die Rechtsentwicklung mit Quelledokumentation. Band 4 - Tschechoslowakei (1944-1989). Frankfurt am Main: Vittorio Klostermann.

KLÍMA, K. A KOL. (2009) Komentář k Ústavě a Listině. 1. a 2. díl. Plzeň: Aleš Čeněk.

KOUDELKA, Z., ŠIMÍČEK, V. K právní povaze Listiny základních práv a svobod. In Právník. No. 2. KRÁL, J. A KOL. (2004) Ústavné garancie ludských práv. Bratislava: Vydavatel’ské oddelenie Právnickej fakulty Univerzity Komenského v Bratislave.

KuBINA, P. (2003) 'Úprava vztahu štátu a katolíckej cirkvi v Slovenskej republike a jej východiská'. In Justičná revue. Vol. 55, No. 2.

KumoR, B., Dlugoš, F. (2004) Cirkevné dejiny 8. Súčasné obdobie, 1914-2000. Levoča: Nadácia Kňazského seminára biskupa Jána Vojtaššáka.

LONDÁKOvÁ, E. (2008) 'Cirkevné školstvo a školská reforma na Slovensku po 2. svetovej vojne'. In Dobrotková, M., Kohútová, M. (eds.) Slovensko a Svätá stolica. Trnava: Slovenský historický ústav v Ríme - Trnavská univerzita v Trnave.

MADLEŇÁKOVÁ, L. (2010) Výhrada svědomí jako součást svobody myšlení, svědomí a náboženského vyznání. Praha: Linde.

MACHÁČKOVÁ, L., DOJČÁR, M. (2000) 'Registrované cirkvi a náboženské spoločnosti v Slovenskej republike v roku 1999'. In Moravčíková, M., Valová, E., Lojda, M. (eds.) Ročenka Ústavu pre vzt’ahy štátu a cirkví 1999. Bratislava: Ústav pre vztahy štátu a cirkví.

MARSINA, R. (1985) Metodov boj. Bratislava: Obzor.

MAŠL̇ANYOVÁ, D. (2012) 'Postih extrémizmu podla slovenského Trestného zákona'. In Záhora, J. (ed.) Aktuálne otázky trestného zákonodarstva. Pocta prof. JUDr. Milanovi Čičovi, DrSc. et mult. Dr. h. c. $k$ 80. narodeninám. Zborník príspevkov z celoštátnej konferencie s medzinárodnou účastou konanej dňa 19. januára 2012. Bratislava: Paneurópska vysoká škola.

MCCREA, R. (2014) Religion and the Public Order of the European Union. Oxford: Oxford University Press.

MiLO, D. (2005) Rasistický extrémizmus v Slovenskej republike. Bratislava: L’udia proti rasizmu. 
MORAVČíkOVÁ, M. (2003) ‘Štát a cirkev v Slovenskej republike’. In Jozefčiaková, p. (ed.) Štát a cirkev v postsocialistickej Európe. Bratislava: Ústav pre vztahy štátu a cirkví.

MoRAVČíkovÁ, M. (ed.) (2007) Výhrada vo svedomí. Conscientious Objection. Bratislava: Ústav pre vztahy štátu a cirkví.

NEMEC, M. (1997) Vybrané kapitoly z cirkevného práva. Bratislava: Manz a Právnická fakulta Univerzity Komenského v Bratislave.

NEMEC, M. (2013) 'Religion and Criminal Law in the Slovak Republic'. In Doe, N., Kotiranta, M. (eds.) Religion and Criminal Law - Religion et Droit Pénal. Leuven: Peeters, pp. 233-240.

NEMEC, M. (2019) 'Kánonickoprávne východiská a sekulárne prístupy k problému ekonomického zabezpečenia cirkví v Slovenskej republike'. In Vladár, V. (ed.) Verejné právo na Slovensku a v Európe - aktuálne problémy a rímsko-kánonické súvislosti. Zborník z medzinárodnej vedeckej interdisciplinárnej konferencie uskutočnenej 27. septembra 2019 na Právnickej fakulte Trnavskej univerzity $v$ Trnave. Praha: Leges.

OREndÁč, P. (2014) Odkaz sv. Cyrila a Metoda a edukačný process. Bratislava: Metodickopedagogické centrum.

OROSZ, L. A KOL. (2009) Ústavný system Slovenskej republiky (doterajší vývoj, aktuálny stav, perspektívy). Košice: Univerzita Pavla Jozefa Šafárika v Košiciach, Právnická fakulta.

PAVLÍČEK, V. A KOL. (2004) Ústavní právo a státověda. II. díl, část’ 2. Praha: Linde.

PEHR, M., ŠEBEK, J. (2012) Československo a Svatý stolec. Od nepřátelství ke spolupráci (19181928). I. Úvodní studie. Praha: Masarykův ústav a Archiv Akademie věd ČR.

PEŠEK, J., BARNOVSKÝ, M. (1997) Štátna moc a cirkvi na Slovensku 1948-1953. Bratislava: VEDA - Vydavatel'stvo Slovenskej akadémie vied.

PEŠEK, J., BARNOVSKÝ, M. (1999) Pod kuratelou moci. Cirkvi na Slovensku v rokoch 1953-1970. Bratislava: VEDA - Vydavatel'stvo Slovenskej akadémie vied.

POLÁČEK, P. (2007) 'Výhrada vo svedomí v judikatúre Európskeho súdu pre l’udské práva'. In Moravčíková, M. (ed.) Výhrada vo svedomí. Conscientious Objection. Bratislava: Ústav pre vztahy štátu a cirkví.

ROBBERS, G. (2000) 'Vztah státu a církve v Evropě'. In Revue církevního práva. Vol. 6, No. 2.

ŘEPovÁ, J. (2004) 'Poznámky k právnímu postavení církví v USA a Evropě'. In Loužek, M. (ed.) Vztah církví a státu. Sborník textů. Praha: Centrum pro ekonomiku a politiku.

ŠABO, M. (2008) 'Vývoj náboženskej slobody na Slovensku do r. 1989'. In Grešková, L. (ed.) Vztahy štátu a cirkví v Európe: Súčasné otázky a trendy na začiatku 21. storočia. Zborník z rovnomennej medzinárodnej konferencie, ktorú usporiadal Ústav pre vzṫahy štátu a cirkví $v$ Bratislave $v$ dňoch 8-10. novembra 2007. Bratislava: Ústav pre vztahy štátu a cirkví, Bratislava.

ŠIMULČíK, J. (1999) Katolícka cirkev a nežná revolúcia 1989. Prešov: Michal Vaško.

ŠMID, M. (2001) Základná zmluva medzi Svätou stolicou a Slovenskou republikou s komentárom. Bratislava: Konferencia biskupov Slovenska

SUCHÁNEK, R. (2002) Modus vivendi. In Revue církevního práva. Vol. 8, No. 3.

SURMÁNEK, Š. (2009) Klerikalizácia verejného života na Slovensku ako prejav a dôsledok silnejúceho vplyvu Katolíckej cirkvi. Košice: Elfa.

SvÁK, J., CiBUlKA, L. (2006) Ústavné právo Slovenskej republiky. Bratislava: Poradca podnikatel'a.

TAYLOR, P. M. (2005) Freedom of Religion: UN and European Human Rights Law and Practice. Cambridge: Cambridge University Press.

TreterA, J. R. (2002) Stát a církve v České republice. Kostelní Vydří: Karmelitánské nakladatelství.

VAlEš, V. (2008) Konfesní právo. Průvodce studiem. Plzeň: Aleš Čeněk. 
VAŠKO, V. (2004) Dům na skále. Církev zkoušená 1. 1945-začátek 1950. Kostelní Vydří: Karmelitánské nakladatelství.

VOZÁR, J. A KOL. (2015) Sloboda prejavu v rozhodnutiach súdov. Bratislava: VEDA.

VRTEL, L. (2010) Štátne symboly Slovenskej republiky. Bratislava: VEDA.

WAGNEROVÁ, E., ŠIMÍČEK, V., LANGÁŠEK, T., POSPÍŠIL, I. A KOL. (2012) Listina základních práv a svobod. Komentářr. Praha: Wolters Kluwer.

WIERER, R. (1935) Uznání a právní postavení náboženských společností podle zákona z 20. května 1874, č. 68 ř. z. Praha - Brno: Orbis.

WitTe, J., JR., GREen, M. CH. (eds.) (2012) Religion and Human Rights. Introduction. Oxford: Oxford University Press.

WolterstorfF, N. P. (2012) 'Christianity and Human Rights'. In Witte, J., Green, M. (eds.) Religion and Human Rights. Introduction. Oxford: Oxford University Press.

\section{Legal sources}

Č. 245/2008 Z.z. o výchove a vzdelávaní, Školský zákon

Deklarácia č. 11 o postavení cirkví a náboženských spoločností a nenáboženských organizácií tvoriaca prílohu Záverečného aktu Amsterdamskej zmluvy z roku 1999

Dohoda medzi Slovenskou republikou a registrovanými cirkvami a náboženskými spoločnostami o náboženskej výchove a vzdelávaní publikovaná pod č. 395/2004 Z.z.

Dohoda medzi Slovenskou republikou a registrovanými cirkvami a náboženskými spoločnostami o výkone pastoračnej služby ich veriacim v ozbrojených silách a ozbrojených zboroch Slovenskej republiky publikovaná pod č. 270/2005 Z.z.

Dohoda medzi Slovenskou republikou a registrovanými cirkvami a náboženskými spoločnostami publikovaná pod č. 250/2002 Z. z

Etický kódex zdravotníckeho pracovníka, príloha k zákonu č. 578/2004 Z.z. o poskytovateloch zdravotnej starostlivosti, zdravotníckych pracovníkoch, stavovských organizáciách v zdravotníctve a o zmene a doplnení niektorých zákonov

Nález Ústavného súdu Slovenskej republiky sp. zn. 10/08

Nález Ústavného súdu Slovenskej republiky sp. zn. III. ÚS 313/09

Nález Ústavného súdu Slovenskej republiky sp. zn. III. US 64/00

Nález Ústavného súdu Slovenskej republiky sp. zn. PL ÚS 18/95

Nariadenie Ministerstva vnútra SR č. 45/2004 o postupe v oblasti boja s extrémizmom a o zriadení monitorovacieho strediska rasizmu a xenofóbie

Nariadenie Slovenskej národnej rady č. 5/1944 Zb. n.

Správa o stave vysielania v Slovenskej republike a o činnosti Rady pre vysielanie a retransmisiu za rok 2013

Ústavný zákon č. 100/1960 Zb, Ústava Československej socialistickej republiky

Ústavný zákon č. 121/1920 Zb., Ústavná listina Čekoslovenskej republiky

Ústavný zákon č. 23/1991 Zb., ktorým sa uvádza Listina základných práv a slobôd

Ústavný zákon č. 4/1993 Sb. o opatřeních souvisejících se zánikem České a Slovenské Federativní Republiky

Ústavný zákon č. 460/1992 Zb., Ústava Slovenskej republiky

Vládne nariadenie č. 124/1928 Zb. z. a nar. o úpravě platů duchovenstva 
Vyhlásenie Národnej rady Slovenskej republiky o umiestňovaní náboženských symbolov v školách a vo verejných inštitúciách v súlade s kultúrnou tradíciou krajiny, schválené Národnou radou Slovenskej republiky uznesením z 10. decembra 2009, číslo 1845

Vykonávacie nariadenie č. 362/1919

Zák. čl. 31/1894

Zák. čl. 32/1894

Zák. čl. 43/1895

Základná zmluva medzi Slovenskou republikou a Svätou stolicou vyhlásená pod číslom 326/2001 Z.z. ako oznámenie Ministerstva zahraničných vecí

Zákon č. 11/1918 Zb. z. a nar. o zřízení samostatného státu

Zákon č. 113/1924 Zb. z. a nar.

Zákon č. 122/1926 Zb. z. a nar. o úpravě platů duchovenstva církví a náboženských společností státem uznaných případně recipovaných

Zákon č. 131/2002 Z.z. o vysokých školách

Zákon č. 140/1961 Zb., Trestný zákon

Zákon č. 18/1993 Z.z. o štátnych symboloch Slovenskej republiky a ich používaní

Zákon č. 218/1949 Zb.

Zákon č. 300/2005 Z.z., Trestný zákon

Zákon č. 308/1991 Zb. o slobode náboženskej viery a postavení cirkví a náboženských spoločností

Zákon č. 312/2001 Z.z. o štátnej službe

Zákon č. 320/1919 Zb. z. a nar. o obřadnostech smlouvy manželské, o rozluce a překážkách manželských

Zákon č. 346/2005 Z.z. o štátnej službe profesionálnych vojakov ozbrojených síl Slovenskej republiky

Zákon č. 370/2019 Z.z. o finančnej podpore cirkví a náboženských spoločností

Zákon č. 39/2017 Z.z.

Zákon č. 394/2000 Z.z.

Zákon č. 475/2005 Z.z. o výkone trestu odňatia slobody

Zákon č. 506/2009 Z.z. o ochranných známkach

Zákon č. 575/2001 Z.z. o organizácii činnosti vlády a organizácii ústrednej štátnej správy

Zákon č. 582/2004 Z.z. o miestnych daniach a miestnom poplatku za komunálne odpady a drobné stavebné odpady

Zákon č. 595/2003 Z.z., Zákon o dani z príjmov

Zmluva medzi Slovenskou republikou a Svätou stolicou o duchovnej službe v ozbrojených silách a zboroch publikovaná 28. novembra 2002 pod č. 648/2002 Z.z. ako oznámenie ministerstva zahraničných vecí Slovenskej republiky

Zmluva medzi Slovenskou republikou a Svätou stolicou o katolíckej výchove a vzdelávaní publikovaná 9. júla 2004 pod č. 394/2004 Z. z. ako oznámenie ministerstva zahraničných vecí Slovenskej republiky 